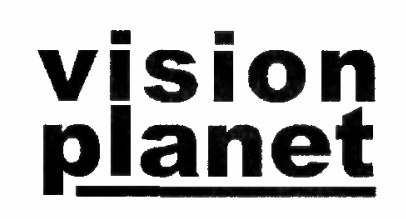

\title{
A KÖZÉP-EURÓPAI, A DUNA MENTI ÉS AZ ADRIAI TÉRSÉG INTEGRÁLT TERÜLETFEJLESZTÉSI STRATÉGIÁJA ${ }^{1}$
}

\author{
Policy Option Paper
}

${ }^{1}$ A tanulmány 1999. május 17-18-ân, a Munkacsoport ötödik értekezletén került elfogadásra. A három EU tagállam VISION PLANET-hez való hozzájárulásának finanszírozásában részt vett az INTERREG II C Közösségi Kezdeményezés. 


\section{ELÖSZÓ}

Az alábbiakban egy olyan tanulmányt (VISION dokumentum) adunk közre, amely a közép-európai, a Duna menti és az adriai térségre (CADSES) fogalmaz meg közös jövőképet, cselekvési irányokat. Az INTERREG II C program keretében megvalósuló tervezési projekt célja, hogy segítse Európa e térségének integrációját, ezen keresztül pedig a nem tagországok Európai Uniós csatlakozásra történó felkészullését. A program másodlagos célja egy olyan tervezói hálózat kialakítása a CADSES térségben, amely folyamatos párbeszédet alakít ki a területi tervezés szereplöi között.

A tervezés hatásterullete, a földrajzi értelemben vett Európa mintegy hatodára terjed ki, és népességének közel negyedét érinti. Összességében 17 ország alkotja a CADSES régiót, mint európai tervezési régiót, melyek közül három (Ausztria, Németország és Olaszország) tagja az Európai Uniónak. Ez a tanulmány egy másfél éves tervezői folyamat eredménye, melynek formálásában - a német Bundesamt für Bauwesen und Raumordnung (Építésügyi és Területfejlesztési Szövetségi Hivatal) koordinálásával - 12 ország vett részt aktívan. Magyarországot a VÁTI Kht. és az MTA Regionális Kutatások Központja képviseli a programban.

A VISION dokumentum vitaanyag. A tervezői csoport szándéka, hogy valamennyi érintett ország területfejlesztési szakemberei és a területfejlesztésért felelös politikusai megismerjék a tanulmányt, és véleményt formáljanak arról. Ezt szolgálja a dokumentumnak a Tér és Társadalomban történő bemutatása, valamint 1999. ösz folyamán szakmai fórumok szervezése. A VISION dokumentum angol nyelvŭ hátttéranyagai az alábbi címeken elérhetók, illetve írásos vélemények is e címekre küldhetők:

Lados Mihály

MTA RKK NYUTI

9002 Györ, Pf. 420.

Tel. 96516570

Fax: 96516579

ladosm@edo.rkk.hu
Vajdovichné Visy Erzsébet

VẢTI Kht.

1016 Budapest, Gellérthegy u. 30-32.

Tel. 13569122

Fax: 13568003

evisy@vati.ktm.hu 


\section{Prológus}

1989-90-ben a hidegháborút követöen, Közép- és Délkelet-Európa egy különleges történelmi pillanatba lépett, amikor megszüntek létezni a térségen belüli ellenséges blokkok, és megnyíltak az átfogó, transznacionális együttmüködés lehetőségei. Közép- és Délkelet-Európa XX. századi történelme során elöször tünt lehetségesnek egy közös fejlesztési stratégia kidolgozása e nagyszámú és jelentős különbségeket felmutató térségre.

A jelen dokumentum írásakor a térségben ủjra feléledt az ellentét és a konfliktus. A Munkacsoport tagjai azonban még mindig meg vannak győződve arról, hogy az együttmúködés tendenciái, és ereje legyőzi a szembenállásokat. A projekt kidolgozása során tapasztalható óriási fejlödés bizonyítja az egyưttmüködés akaratát. A VISION dokumentum hozzájárulhat a térségben a jobb, kölcsönös megértéshez, és ha csak kismértékben is a béke megteremtéséhez. Ugyanakkor hozzájárulhat „Délkelet-Európa Stabilitási Egyezménye" megszövegezéséhez és végrehajtásához is. Azonban a tanulmány szerzöi tisztában vannak azzal, hogy az elkövetkezendö hónapokban és években szükség lesz az itt lefektetett stratégiák újragondolására és módosítására.

A dokumentum a régiókról szól. A térség bemutatása során figyelembe vesszük a belsö különbözőségeket és egyenlötlenségeket, valamint azt, hogy az egyes országok nem homogén területi egységekböl állnak. Mindez egy komplexebb és differenciáltabb megközelítést eredményez. Továbbá valljuk, hogy a régiók a nemzetközi együttmúködés aktív résztvevői, és saját kezdeményezéseik lehetnek. Ez a térségben újabb lépést jelenthet a nagyobb fokú decentralizáció és a demokrácia felé.

A regionális és a határon átnyúló tervezés és együttmüködés nemcsak a világméretủ és kontinentális demokratizálódás eredménye. Az intenzív és folyamatos határon átnyúló és regionális szintủ kapcsolatnak és együttmüködésnek visszacsatoló és megerősitő hatása lehet a nemzeti politikákra, ami egyben a stabilitás és biztonság kiegészitó garanciájának bizonyulhat. A regionális szintü - a nemzeti politikák konfliktusaitól mentes - együttmüködés a régióban élő emberek közötti kölcsönös megértés úttöröje lehet.

A tanulmány röviddel az Európai Unió területfejlesztésért felelös miniszterei által a potsdami értekezleten elfogadott „European Spatial Development Perspective” (Európai Területfejlesztés Perspektívája - ESDP) után jelent meg. Bár az ESDP jelenlegi formájában az EU területére korlátozódik, meg vagyunk győződve arról, hogy a VISION dokumentum tartalma ösztönzést adhat az ESDP alkalmazására a jelenlegi és a jövöbeli tagállamok számára egyaránt. 


\section{Bevezetés}

\section{A kezdeményezés}

Európaszerte egyre inkább felismerik a politikai és közigazgatási szereplök az integrált európai területi tervezési politika szükségességét. Az európai transznacionális területi tervezés két alapvető dokumentumában - a „Principles for a European Spatial Development Policy” („Leipzig document”) - (Az európai területfejlesztési politika alapelvei /Lipcsei dokumentum/), és az ESDP-ben - lefektetett alapelvek és politikai választási lehetőségek részeként, az Európai Unió elindította a Közösségi Kezdeményezések INTERREG II C programot. Az INTERREG II C célja a területi tervezés területén történö együttmüködés támogatása a nagy európai makrorégiókban. Számos INTERREG II C programot dolgoztak ki, ezek közé tartozik az EU tagállam Ausztria, Görögország, Németország és Olaszország kormányainak kezdeményezésére a közép-európai, az adriai, a Duna menti és a délkelet-európai térségre (rövidítve CADSES) vonatkozó program is. A programban felölelt térség Ausztria, Németország és Olaszország egy részét, illetve Görögország teljes területét magába foglalja. A közép- és délkelet-európai országok közül a programtérség Albániát, Bosznia-Hercegovinát, Bulgáriát, a Cseh Köztársaságot, Horvátországot, Jugoszláviát, Macedóniát (FYROM), Magyarországot, Moldovát, Romániát, Szlovákiát és Szlovéniát, valamint Lengyelország és Ukrajna egyes részeit tartalmazza.

1997 folyamán az Osztrák Köztársaság Szövetségi Kancelláriája kidolgozott egy projektjavaslatot, amely egyrészt tervezőkből, hivatalnokokból, és szakértőkből álló hálózat létrehozására, másrészt a CADSES térségben történő területi tervezés céljainak, megközelítési módjainak, módszereinek és eszközeinek közös kialakítására irányult. Ugyanakkor a német Építésügy és Területfejlesztés Szövetségi Hivatala egy transznacionális szakértỏi csoport keretében projekt javaslatot kezdeményezett a "Vision and Strategies for Spatial Development in the Central European and Danubian Area" (A területfejlesztés jövőképe és stratégiái a közép-európai és a Duna menti térségben) dokumentum kidolgozására. A két kezdeményezés egyesitéséböl származó egyértelmü elönyök vezettek el a VISION PLANET (utóbbi a PLANing - tervezés és a NETwork - hálózat rövidítésekböl áll össze) elnevezésü projekthez. Még a projekt jóváhagyása elött, az Olasz Köztársaságot képviselve, Friuli-Venezia Giulia Régió is kinyilvánította érdeklödését, s kezdeményezte részvételét. Ennélfogva a vizsgált térséget kiterjesztették az adriai területre is. A kezdeményezésekkel párhuzamosan Görögország is inditványozta az ESTIA projekt megvalósítását a délkelet-európai, mint a CADSES térségen belüli makro-régió területfejlesztési politika integrációjának célját.

Ezen együttmüködés alapgondolatait 1997 októberében mutatták be a kezdeményezők a térség országait képviselöknek. Az első formális találkozó megtartására valamennyi érdekelt ország részvételével 1998 januárjának végén került sor. A következő hónapokban a térség 11 országának képviselői megegyeztek a célokban, 
illetve az együttmüködési folyamat struktúrájában és tartalmában. Ez a dokumentum - a továbbiakban ,VISION dokumentum” - a közös eröfeszítések elsó kézzelfogható eredménye.

A VISION dokumentumot egy nemzetközi munkacsoport dolgozta ki, melynek tagjai Ausztria, Bulgária, a Cseh Köztársaság, Horvátország, Lengyelország, Magyarország, Németország, Olaszország, Románia, Szlovákia, Szlovénia, továbbá Szerbia - mint a Jugoszláv Szövetségi Köztársaság része - területi tervezési szakértői. A koordináció feladatára a német Bundesamt für Bauwesen und Raumordnung-ot (Építésügyi és Területfejlesztési Szövetségi Hivatal) jelölték ki. A csoport munkáját egy fủggetlen szakértói csoport támogatása mellett a résztvevó országok hivatalos képviselöinek fóruma kísérte és vezette.

Vannak olyan országok a térségben, amelyek képviselői - ez idáig - különböző okok miatt nem tudtak ténylegesen részt venni a dokumentum kidolgozásában és megtárgyalásában. Ezek a következő országok: Albánia, Bosznia-Hercegovina, Montenegro $^{2}$, Macedónia, Moldova és Ukrajna. A VISION PLANET résztvevőinek ambiciózus célja, hogy a programtérség összes országát bevonja a transznacionális területi tervezés együttmüködésének további folyamatába.

A VISION PLANET-et képviselö partnerek a CADSES térségen belül szorosan együttmüködnek egy másik INTERREG II C projekttel: az ESTIA projekttel. Az ESTIA központi célja az alkotóelemek meghatározása, és így a területfejlesztési politika integrációja, illetve a részt vevő országok közỏtti együttmúködés megerősítése hátterének biztosítása. A cél elérése érdekében a projekt a délkelet-európai területfejlesztési trendek, távlatok és politikák tanulmányozására fókuszál, különös hangsúllyal Görögországra, Bulgáriára és Romániára, a CADSES tágabb összefüggésében. Megfigyelöként meghívást kapott Albảnia, Jugoszlávia és Macedónia is azzal a lehetőséggel, hogy teljes jogú tagként integrálódjanak. A tanulmány megkỏzelítési módja, módszere és eredményei várhatóan jelentős mértékben általánosíthatóak lesznek a CADSES térség többi országára is. A CADSES és az ESTIA partnerei a projekt szintü integráció erősítése érdekében fokozni szeretnék együttmủködésüket a projektek következő szakaszában.

\section{A VISION Dokumentum}

A dokumentum az intézkedések azon három körére fókuszál, amelyek a Lipcsei Dokumentumban kerületek megfogalmazásra: a kiegyensúlyozott és policentrikus városhálózat fejlesztése; az infrastruktúrához és tudáshoz való hozzáférhetôség egyenlöségének biztosítása; a fenntartható fejlódés és a természeti és kulturális örökség körültekintő kezelése. Céljai, tartalma és módszerei számos tekintetben hasonlóak más, fontos európai transznacionális területi tervezéssel és fejlesztéssel kapcsolatos dokumentumokéhoz, mint például az ESDP, a „Guiding Principles of

${ }^{2}$ Szerbia, mint a Jugoszláv Szövetségi Köztársaság része az 1999. márciusi Trenčianske Teplicei (Szlovákia) munkamegbeszéléstől kezdve aktívan bekapcsolódott a VISION dokumentum formálásába. 
Sustainable Spatial Development on the European Continent" (A fenntartható területfejlesztés irảnyelvei az európai kontinensen - Európa Tanács), vagy a „Vision and Strategies Around the Baltic Sea 2010" (Jövőkép és stratégiák a Balti-tenger térségében 2010 - VASAB 2010). Ugyanakkor alapvetó különbségek is felfedezhetők a VISION és a fent említett dokumentumok között. A tartalomban és a módszertanban rejlö különbségek a CADSES térségben lévő országok eltérő összetételének, és azok kidolgozási idöpontjának, illetve az elkészült dokumentumok kidolgozása óta történt ủj fejleményeknek a következményei:

- Közép és Délkelet-Európában a legtöbb ország a közelmúltig úgynevezett szocialista ország volt, túlnyomórészt államosított, vagy kollektivizált vagyonnal. Ezek az országok az átalakulás nehéz folyamatát tapasztalták meg az elmúlt évtizedben, melynek - a nyilvánvaló és jól ismert politikai, társadalmi és gazdasági következmények mellett - szerteágazó területi és regionális hatásai is voltak. Feltétlenül szükséges megvizsgálni a területi átalakulás folyamatait és azok hatásait, illetve következtetni a térség országaiban a területfejlesztési politikáért felelős hatóságok közötti jövöbeni együttmüködésre. A VISION dokumentum az elsỏ olyan transznacionális területi tervezési dokumentum, amely átfogóan tartalmazza az átmenet területi problémáit.

- Európa közép- és délkelet-európai térsége hét, az Európai Unióval „társult országot" foglal magába. A csatlakozás követelményei komplex és széleskörũ hatásokkal járnak a területfejlesztésre, ezért szükség van azok mélyreható elemzésére és értékelésére.

A VISION dokumentum egyik fö célja a területi kohézió és integráció erösítése Európának ezen a részén. Ezért a dokumentum legnagyobb részében az egész térséget egységes térségként kezeli. Nem tesz különbséget a térségben az Európai Unió tagállamai és a többi ország között. Minden ország résztvevöje a jövóbeni európai integrációs folyamatnak.

A VISION dokumentum transznacionális dokumentum. A „transznacionális” kifejezést azonban nem - vagy nem csak - a több ország által alkotott terület triviális jelentéseként használjuk. A mi értelmezésünk szerint a következöket jelenti:

- a VISION dokumentum elsö sorban is a területfejlesztés közös vonásai és a területfejlesztési politika közös kihívásai iránt érdeklődik. Nem tartalmaz olyan fejezetet vagy részt, mely az egyes országokra vonatkozna;

- a legtöbb részt vevő ország rendelkezik kidolgozott saját nemzeti területfejlesztési koncepcióval. A VISION dokumentum szerzőinek nem szándéka sem rivalizálni a nemzeti koncepciókkal, sem megbolygatni azokat. $A$ több országot átfogó térségek esetében a konkrét intézkedésekre vonatkozó minden politikai vảlasztási lehetőséget és jovaslatot transznacionálisként fogalmaznak meg, ezért a VISION dokumentum kiegészíti, nem pedig helyettesíti a nemzeti koncepciókat.

A konkrét intézkedésekre vonatkozó politikai választási lehetöségek és javaslatok, amelyek a VISION dokumentumban összegzésre kerülnek, általános orientációt kínálnak és nem kötelező jellegũek. Mindamellett a térségben minél több az olyan 
ország, amely egyetért a célkitüzések támogatásával, s a dokumentum alapvető javaslataival, annál nagyobb az esély azok figyelembevételére, megvalósítására.

A dokumentum javaslatainak címzettjei:

- a nemzeti kormányzatok, hogy nemzeti területfejlesztési koncepciójuk és programjaik kidolgozása illetve felülvizsgálata, valamint az ágazati politikák kialakítása során vegyék figyelembe azokat;

- az Európai Bizottság és az Európai Unió más intézményei, azzal a kéréssel, hogy vegyék tekintetbe a következö INTERREG III programozási periódus keretének kialakítása, illetve a PHARE, ISPA és SAPARD előcsatlakozási eszközök megvalósítása során;

- a nemzetközi pénzintézetek és befektetók, mint a térség jövöképére és stratégiáira vonatkozó informális irány;

- a regionális és helyi kormányzatok, hogy információhoz jussanak a transznacionális környezetről és feltételekről, amelyek befolyással vannak saját területi és ágazati politikájuk kidolgozására;

- a nem kormányzati szervezetek, amelyek érdekeltek, vagy részt vesznek a területfejlesztési kérdésekben, föleg regionális és helyi szinten;

- és végül a területi tervezök, a regionális politika kidolgozói, valamint a regionális tudománnyal foglalkozók szakmai közössége, hogy ezzel is hozzájáruljunk a térség problémáinak jobb megértéséhez.

A VISION PLANET-et három EU tagország, Ausztria, Németország és Olaszország kezdeményezte. $A$ hangsúlyt azonban nem ezen országokra, hanem a VISION térség nem EU tagállamainak fejlődésére, és azok egymás közötti, illetve a három EU tagállammal való kapcsolataira helyezi. A különbség magyarázata egyértelmü: számos egyéb intézmény, pénzügyi rendelkezés és dokumentum (köztük az ESDP is) létezik már, amelyek az EU tagállamok számára az együttmüködés elösegitését szolgálják, s területi politikai ajánlásokat tartalmaznak. A VISION PLANET fó szerepe, hogy az EU tagállamok számára figyelemmel kísérje az Európai Unió jelenlegi határain túli ,,külvilágot”, és erösítse a területi tervezés terén az együttmüködést ezen országokkal.

A VISION dokumentum kidolgozása egy politikai és egy elemzési folyamat egyszerre. Politikai abbaiı az értelemben, hogy a dokumentum tartalmára vonatkozó egyeztetés egy politikai folyamat, és - következésképpen - a dokumentumot be fogják mutatni a részt vevö országok hivatalos képviselöinek. Elemzési abban az értelemben, hogy a VISION PLANET-en belüli együttmüködés lehetővé teszi a tagok számára, hogy értékelhessék a térség területfejlesztési folyamatait, kialakítsák e folyamatok közös értelmezését, és kidolgozzák a területi tervezés közös alapelveit.

A köveielményekkel összhangban a dokumentum két fö részböl áll:

- A „Policy Option Paper" (Politikai Jovaslatok jelen tanulmány) - tartalmazza a CADSES térségben a területi tervezéssel kapcsolatos együttmúködések legfontosabb céljait és politikai választási lehetőségeit, illetve a szakértői csoport által javasolt intézkedéseket, melyeket a részt vevő országok hivatalos képviselöi fogadnak el; 
- A „Background Report” (Háttérjelentés) - tartalmazza a közös kidolgozási folyamat legfontosabb hozzájárulásait és eredményeit, amelyek alapként és magyarázatként szolgálják a „politikai” dokumentumban leírt célokat és intézkedéseket. Ezt a Munkacsoport a következö hónapokban (1999. év végéig) fogadja el.

A fenti definícióból következik, hogy a két rész - bár tartalmában harmonizál, és kiegészíti egymást - különböző célokat szolgál, és funkciójukat csak akkor teljesithetik, ha azokat külön-külön kezeljük.

\section{VISION tér}

A VISION projekt egy 1,486 millió $\mathrm{km}^{2}$ nagyságú és 187 millió lakosságú teruletet ölel fel. Az európai földfelszín 6,4\%-át (Oroszország nélkül 21,5\%-át) és a népesség 25\%-át reprezentálja. Összesen 17 európai országot foglal magába, ezek közül 12-nek a teljes területét (Albánia, Bosznia-Hercegovina, Bulgária, Cseh Köztársaság, Horvátország, Jugoszlávia, Magyarország, Macedónia, Moldova, Románia, Szlovákia és Szlovénia) és ötöt részben (Ausztria, Lengyelország, Németország, Olaszország és Ukrajna). Figyelembe véve Görögországot és az ESTIA projektet a térség mérete és jelentősége tovább nő.

A térség a társadalmi, gazdasági és földrajzi helyzetre vonatkozóan hatalmas különbségekkel jellemezhetö:

- A gazdaság fejlettségi szintje rendkívül eltérỏ a térségben. A VISION térségben található Európa néhány legfejlettebb régiója (Bécs, Baden-Württenberg, Bajorország, Emilia-Romagna), de itt vannak Európa legfejletlenebb térségei is (Koszovó, Albánia, Macedónia). A különbségek a keleti VISION térségen belül is jelentősek ${ }^{3}$.

- A gazdasági és foglalkoztatottsági szerkezet is rendkívül eltérō. Néhány keleti VISION országban a mezőgazdasági foglalkoztatás Bajorország, Olaszország és Ausztria alacsony szintjéhez hasonló (4-7\%), míg más országokban jóval magasabb (25-40\%), és az elmúlt években még növekedett is.

- Ugyanez a helyzet a demográfiai adatok esetében is. Európa legmagasabb (Albánia, Macedónia) és legalacsonyabb (Németország, Olaszország) születési rátájú országai is a VISION térségben találhatók. Hasonlóan a térségben találhatók az európai országok közül a legmagasabb (Magyarország) és a legalacsonyabb (Albánia, Macedónia) halálozási rátájú országok is. Következésképpen a természetes népességváltozás szintén rendkívül különbözö.

${ }^{3}$ E dokumentumban a „keleti VISION országok” és a „VISION térség keleti fele” kifejezések alatt a következő területet értjük: azon országokat, amelyek - jelen pillanatban - nem tagjai az Európai Uniónak, valamint Németország új tartományai. Ez a megközelítés földrajzilag nem teljesen korrekt: néhány „keleti” ország földrajzi helyzete sokkal nyugatibb, mint egy-két ,nyugatinak”. Mindamellett a „nem EU tagország” negatív fogalma sem helyesebb, továbbá csak egy - bár igen fontos - politikai szempontot vesz figyelembe. A visszapillantó „volt szocialista országok” kifejezés ideológiai karakterủ és szintén inkább félreérthetö. Egy „területi” dokumentumot készítve a „keleti” földrajzi fogalom használatával értettünk egyet, annak ambivalenciája ellenére is. 
A szélsőséges eltérések mellett fontos közös jellemzői is vannak a térségnek, amelyek szükségessé teszik az együttes erőfeszitéseket a jövőbeli területfejlesztés érdekében.

- A térség valamennyi országa osztozik a viharos XX. századi történelmen. A történelemnek csak egy jellemzöjét említsük: a térségben a szárazföldi határok hossza $16000 \mathrm{~km}$. Ebböl csak $420 \mathrm{~km}$ olyan, ahol sem a határvonal, sem a szomszédos országok nem változtak meg a XX. század folyamán: ez a Románia és Bulgária között húzódó Duna határ egy része (nem a teljes). A VISION térségben a határoknak több mint 95\%-a módosult a század során, néhány többször is.

- Míg a VISION országok egy része a mediterrán térséghez tartozik, a térség nagy része inkább szárazföldinek tekinthetô. A részt vevó 17 ország közül hatnak egyáltalán nincsen tengerpartja, a többiek nagy többsége is mindössze egy viszonylag rövid partszakasszal rendelkezik. Míg az Európai Unióban a határok $84 \%$-a tengerparti határ, addig ugyanez a szám a VISION térség esetében mindössze $31 \%$. A VISION térség szárazfơldi határainak hossza meg. haladja a teljes Európai Unióét.

- A 17 VISION országból 15-ben (beleértve Kelet-Németországot is) majd fél évszázadon keresztül olyan rendszer volt az uralkodó, amelyben a termelési eszközök állami vagy szövetkezeti tulajdonban voltak, a gazdaságot központi tervutasítás irányította, $s$ egy párt hegemóniája jellemezte az ơsszes politikai, igazságszolgáltatási, kulturális, társadalmi és oktatási intézményt. A Szovjetunió nagy erőfeszítéseket tett, bár nem teljes sikerrel, hogy ezen országokban is létrehozza ugyanazokat az egységes struktưrákat és intézményeket. Következésképpen az átmenet kihívásaival szembenézve minden ország számára hasonló a kiinduló helyzet, amely lehetővé teszi a közös területfejlesztési stratégia néhány elemének kialakítását. E közös örökség ellenére azonban az egyes országok fejlödésének irányai határozottan eltérỏek voltak az elmúlt évtizedben.

- A belsỏ kohézió egyik eleme a térségen belüli intenzívebb gazdasági és kereskedelmi kapcsolatok hálózata. Annak ellenére, hogy az országok hosszú ideig különböző gazdasági blokkhoz tartoztak, a VISION térség két fele közötti gazdasági kapcsolatok sohasem szüntek meg, s a politikai változásokat követỏen igen gyorsan megszaporodtak. Ma a 17 VISION országból 12-ben meghaladja az 50\%-ot a VISION térségen belüli kereskedelem. Még azokban az országokban is, amelyek esetében ez nemzeti szinten nem jellemző (Németország, Olaszország, Ukrajna), a részt vevő régióknak jóval intenzívebb kapcsolatai vannak a VISION térséggel.

- Végül, de nem utolsó sorban a VISION térség valamennyi országa az európai integrációs folyamat részesévé szeretne válni. Az elörehaladás e téren igen eltéró, némelyikük már EU tagország, néhányuk csatlakozásra váró ország, és vannak, amelyek még nem érték el ezt a státuszt sem. A kezdeményezés azonban már mindenhol jelen van. A területi tervezési együttmükődés fontos lépés lehet és kell, hogy legyen ezen integrációs folyamatban. 
A VISION térségben tapasztalható különbségeket és hasonlóságokat figyelembe véve a Munkacsoport javaslatot tesz néhány nagyobb régió megkülönböztetésére, amely lehetỏvé teszi a térségek, mint beavatkozási teruletek sajátos területfejlesztési problémáinak kőzvetlen kezelését. A régiók földrajzi helyzet, természeti adottság, a gazdasági együttmúkődés közős hagyományai és a gazdasági, társadalmi struktúra számos közös vonása alapján alkothatnak egységet. A régióknak nem szükséges az országhatárokat követniuuk. Több ország térségeit is magukba foglalhatnák, egymást átfedhetik, egy adott térség egynél tỏbb régióhoz is tartozhat. A régiókat a VISION PLANET nem irhatja elö. A projekt és a dokumentum a beavatkozási teruletek lehetséges kritériumainak meghatározásával inkább a nemzeti, a regionális és a helyi szereplők közötti együttmúködés elősegítést célozza meg.

\section{A területfejlesztési politika alapvetó célkitüzései a VISION térségben}

A VISION térség teljes teruletére kőzőss a terưletfejlesztés négy alapvetỏ célkitüzése:

1) A területfejlesztési politikának a gazdaság és az infrastruktúra térszerkezetének, valamint a versenyképességének fejlesztésével hozzá kell járulnia egy hatékonyabb, dinamikusabb és szilárdabb gazdasági és társadalmi fejlödéshez (a versenyképesség, a hatékonyság és a növekedés célkitüzése);

2) A területfejlesztési politikának a gazdasági, társadalmi és területi kohézió erősítésével, illetve az elmaradottság, vagy a strukturális átalakulás problémáival küzdô régiók támogatásával hozzá kell járulnia egy kiegyensúlyozottabb gazdaság- és társadalomszerkezet létrejöttéhez (a kiegyensúlyozott fejlódés és a kohézió célkitüzése);

3) A teruletfejlesztési politikának a jövő generációja érdekében hozzá kell járulnia a természeti és kulturális örökség megörzéséhez, a fejlödés és az eröforrásfelhasználás fenntarthatóságához, valamint a kơrnyezet megóvásához (a környezet és a természeti és kulturális örökség megóvásának célkitũzése);

4) A területfejlesztési politikának hozzá kell járulnia az államhatárok minél jobb átjárhatóságához az interakciók és kapcsolatok számára, a régiók és a városok jobb elérhetőségéhez, s ezzel az időbeli, gazdasági, társadalmi és fizikai távolságok leküzdéséhez, illetve a kőzös, vagy egymáshoz kapcsolódó feladatok egyllttes és kooperáción alapuló megoldásához ( $a z$ integráció célkitũzése).

Versenyképesség, hatékonyság és növekedés

A VISION térség keleti felének államai viszonylag kevésbé fejlett országok. Keleten dinamikusabb fejlödésre van szükség, hogy mérséklödjön a jóléti és fejlettségbeli szakadék a kontinens két fele között. A dinamikus növekedés elöfeltétele a versenyképesség és a hatékonyság növekedése. Az EU országok néhány régiója (mint Kelet-Németország, Burgenland, Dél-Olaszország) ugyanezen feladatokkal néz szembe. A megfelelő területfejlesztés tartósan javíthatja a hatékonyság és a növekedés elöfeltételeit. 
A keleti VISION gazdaságok müködését és fejlödését évtizedekig nem a piaci feltételek befolyásolták. Ezek területi szerkezete sok szempontból messze van az optimálistól: funkcionális szállitási igényuuk többszörösen magasabb az összehasonlítható piacgazdaságokénál; az infrastruktúra hiánya akadályozza a hatékony és a folyamatos együttmüködést; a termelési tényezők valós piaci árának hiánya felelös számos rossz és nem megfelelö telepítési döntésért; a verseny hiánya pedig évtizedeken keresztül lehetővé tette sok, nem hatékonyan müködő termelö egység fennmaradását. A kiegyensúlyozott és koherens területi átszervezés jelentős gazdasági haszonnal járhat a hatékonyság és növekedés szempontjából.

A növekedés elősegitése érdekében a VISION országokban a regionális politikát nem szabad kizárólagosan csak a szegény vagy a válságos helyzetben lévő régiókra fókuszálni. Figyelembe veendö, hogy a legtöbb országban a versenyképesség, a külföldi beruházások, az export és a növekedés jelenleg csak néhány régióra, illetve városra jellemzỏ. A nemzetgazdaság egészének életbevágóan fontos érdeke, hogy e térségekben a támogatási rendszer hozzájáruljon a jobb üzleti feltételek megteremtéséhez.

Végül, habár az elmúlt évtizedek gazdasági és regionális politikája rengeteg torzulást és hibás fejlesztést eredményezett, azonban nem volt minden rossz - vagy nem hatékonyan müködö -, ami a tervgazdaság keretében jött létre. Ezen időszak alatt kialakult egy kiegyensúlyozottabb városhálózat. Sok helyütt viszonylag jó és hatékony volt a tömegközeledési hálózat, a személy és áru szállitás legfontosabb módjainak relativ súlya kedvezőbb volt, mind gazdaságossági, mind környezetvédelmi szempontból, a túlzott városi terjeszkedést a legtöbb országban sikerült elkerülni, a farmok méret eloszlása - elvileg - lehetővé teszi a hatékonyabb termelést. A hatékonyságra való törekvés azt jelenti, hogy meg kell örizni - amennyire csak lehetséges - azt, ami hatékonynak bizonyult, és csak azon kell változtatni, ami nem az.

\section{Kiegyensúlyozott fejlődés és kohézió}

A területi és regionális politika alapvető célkitűzése, hogy minden régió és a települések minden típusa részesülhessen a gazdasági és társadalmi fejlödés eredményéből. Ennek elérése érdekében a kevésbé fejlett régiók, illetve a komoly strukturális válsággal kủzdő régiók különleges figyelmet és támogatást igényelnek. Hosszú távon kivánatos a fejlettebb és a kevésbé fejlett régiók közötti rés szúkítése, de legalábbis további szélesedésének megelözése.

Az elmaradott vagy komoly válsággal küzdő régiók támogatásánál mindenekelött a fejlődés és növekedés előfeltételeit kell megteremteni. Gyakran szükséges a külső támogatás, de a fejlesztésnek elsósorban az endogén erőforrásokon és a belső versenyképességen kell alapulnia. A külső támogatásnak pedig kiegészitő jellegünek és idöben korlátozottnak kell lenni.

Az eltérő területi növekedés és fejlődés - különösen rövid és középtávon - nem szuikségképpen rossz vagy nemkivánatos. A dinamikus régiók és városok a fejlödés magterületei, amelyek a terjedésen - és részben az újraelosztáson - keresztül hozzájárulhatnak a többi régió fejlödéséhez is. 
A kohézió és a kiegyensúlyozott fejlődés mind nemzetközi, mind nemzeti szinten alapvető követelmény. A különbözö szintek összefủggnek egymással. A fejlesztésükhöz kưlső segítséget váró országoknak igazolniuk kell, hogy megteszik a hatáskörikkbe tartozó szükséges intézkedéseket, s a gazdasági lehetőségeikhez mérten a regionális kohézióra és a kiegyensúlyozott fejlödésre törekednek. A kohézió elérése érdekében a helyi, a regionális, a nemzeti és a nemzetkőzi szereplök közös eröfeszítésére van szükség.

A nagyrégiók szintjén megvalósuló konvergens fejlödés eltakarhatja a kisebb régiók szintjén jelentkezó divergenciát. Ezért fontos meghatározni azokat a területi szinteket, amelyekre a kohézió és a kiegyensúlyozott fejlődés különbözö részei vonatkoznak. Az Európai Unióban ezeket a szinteket a NUTS 2 és a NUTS 3 szintek képviselik. A keleti VISION országoknak meg kell határozniuk ezeket a térségeket.

A kohézió és a kiegyensúlyozott fejlödés céljának eléréséhez az állami és a magán szereplök, illetve a gazdasági-társadalmi fejlödés egyéb szempontjai között az infrastruktúra és a közvetlen üzleti támogatás „kiegyensúlyozott” arányára is figyelni kell.

\section{A környezet és a természeti-kulturális örökség megóvása}

A VISION térség keleti felében lévő országok által követett politikák az utóbbi évtizedekben nem fordítottak kellob figyelmet a környezetre, valamint a természeti és kulturális örökségre. A politikák komoly károkat okoztak a környezetben. Ma ezek az országok egy átmeneti szakaszban vannak, amelynek trendje a jövőre vonatkozóan nem jelezhető teljes bizonyossággal elöre. A korábbi gazdasági szerkezet összeomlása csökkentette a szennyezỏanyag kibocsátást, de az országoknak szembe kell nézniưk a múltban felhalmozódott hatalmas károkkal. Másrészröl új típusú veszélyek jelentek meg, amelyek hatásait ugyancsak szükséges kezelni.

Egy, a mainál jóval inkább környezet-, természet- és kultúrabarát fejlődést kell elösegíteni a kưlönbözö szinteken megvalósuló politikákkal, amelyek egyaránt feltételezik az új technológiák, az új termelési és fogyasztási szerkezetek illetve gyakorlatok alkalmazását, valamint az új intézmények, eszközök és intézkedések bevezetését. A piacgazdasági feltételek között új szabályozásokat kell kialakítani a fenntartható fejlődés támogatására és ösztönzésére, illetve a nagyszámú magán és autonóm gazdasági szereplö számára.

Az emberek attitüdjeiben, szokásaiban várható, de szükséges is, hogy jelentős változás következzen be. Mindez a szocializáció és az oktatás új típusait igényli, amelyek elsődleges feladata, hogy az emberek attitüdjeit a környezet és a természeti örökség felé fordítsák. Meg kell erősiteni a környezet védelme iránti elkötelezettséget. Még a technológiaváltásnál is jóval nehezebb a gondolkodásmódban véghezvinni a szükséges változásokat. 


\section{Az integráció}

Míg az elözỏ három cél általános érvényủ az európai kontinens területfejlesztésében (bár rendelkeznek a VISION térségre vonatkozó különleges vonásokkal), az integráció egy speciális célja e régiónak, mind időben, mind térben. Az integráció különleges kihívás egy olyan terület számára, ahol mintegy $16000 \mathrm{~km}$ szárazföldi határral több kis független állam található, és amelyet számos történelmi, politikai, etnikai és vallási ellentét terhel. Az a tény, hogy a térség országainak többsége már benyújtotta az Európai Unióhoz csatlakozási kérelmét, megerősíti az integrációs cél fontosságát és aktualitását, de az integráció kihívása a térség országaiban mindenképpen felmerült volna.

A világgazdaság rohamosan halad a globalizáció és a szabad kereskedelem felé. A kereskedelmi akadályok fenntartása ezen országok között a liberalizmus és a szabad kereskedelem kontinensén egyet jelentene a kisállamok protekcionizmusának „fenntartásával".

$\mathrm{Az}$ áruk, a töke és az emberek szabad áramlásának nem a vámakadályok az egyedüli korlátjai. A különbözö stanđardok, munkák, igazolások, áruszállítási stb. szabályozások a tényleges integrációnak ugyanolyan komoly korlátjai, mint a vámok. A szabályozások átláthatósága és konvergenciája, a közősségi joganyag (acquis communautaire) egyre több elemének alkalmazása nemcsak az EU csatlakozás követelménye. Az EU csatlakozástól függetlenül elősegíti a közép- és délkeleteurópai országok közötti gazdasági kapcsolatok elmélyítését.

A vámkorlátok és a kúlönbözö szabályozások mellett az európai integrációnak fizikai és infrastrukturális elöfeltételei is vannak. Ide tartozik a kontinens valamennyi pontjának elérhetőségének javítása. Európában a fejlett transznacionális elérhètőség részét képezik: a jól fejlett Transz-Európai Közlekedési Hálózat (TEN), a rendszeres, megbízható és gyors közlekedési és telekommunikációs kapcsolatok, a határátkelőhelyek nagy száma, illetve a gyors és hatékony határátlépési rendszer.

A határok ,spiritualizácio”-ja nemcsak a fizikai és intézményi feltételek felállítását jelenti, hanem a kapcsolatok és az interakciók egy sủrủ hálózatának kialakítását is. Az eurégiók, a városok és a régiók testvérkapcsolata, az infrastruktúra-fejlesztés, a közös természeti és kulturális örökség megóvása területén jelentkező kőzös projektek, a kis- és középvállalkozások és a munkaerő határon átnyúló együttmúködése mind összetevői az európai területi integrációnak.

Az európai integrációs folyamat elkövetkezendỏ négy évre szóló két központi „projektjének” egyike - a pénzügyi unió mellett - a közép- és délkelet-európai országok csatlakozása az Európai Unióhoz. Az európai integrációs folyamat azonban nem korlátozódik csak a csatlakozásra. A kelet és nyugat, illetve a kelet és kelet közötti integrációnak rengeteg eleme van; ezek közül némelyik teljesen független a csatlakozástól, és legalább annyira fontos, mint a tơbbi tényező. 
A célkitüzések közötti kapcsolat és interakció: kiegyensúlyozott és fenntartható területi fejlődés

A FENNTARTHATÓSÁG a teruletfejlesztés különbözö célkitủzéseinek integrációjára jellemző fogalom. Ez olyan fejlödési út követését jelenti, mely hosszú távon fenntartható anélkül, hogy egy generációt is elönyben részesítene a többivel szemben, és anélkül, hogy veszélyeztetné az emberi tevékenységek, illetve a környezet és a természeti erőforrások közőtt kialakult egyensúlyi helyzetet. A területi fenntarthatóság demográfiai, gazdasági, társadalmi, környezeti, természeti és kulturális aspektusokkal és dimenziókkal bír, és tulajdonképpen a kủlönböző aspektusok közötti egyensúlyi helyzet megteremtését jelenti. Különösen fontos meghatározni a fenntarthatóság követelményeit a kritikus átmeneti periódusban, amellyel a VISION térség legtöbb országa most szembenéz. A fenntarthatóságot, mint döntö elvet elösegíteni és támogatni kell a térhasználók és -fejlesztők viselkedésének tervezése és irányítása során.

A társadalmi, gazdasági és környezeti dimenziók KÖLCSÖNÖS FÜGGÉSÉT a területi tervezés és regionális politika integrált módszertanaként ki kell fejteni. Prioritást kell adni azon intézkedéseknek, amelyek egynél több célkitủzés megvalósítását támogatják. Az ELÉRHETÖSÉG tekinthető mind a versenyképesség és növekedés, mind a kiegyensúlyozott fejlődés és a kohézió, mind az európai területi integráció egyik meghatározó eszközének.

A regionális politika és tervezés egyik feladata, hogy a kủlönböző célkitüzések követésével megpróbálja a megfelelö és kívánatos egyensúlyi helyzetet létrehozni. A célkitüzések között nem létezik elsőbbségi sorrend. Az adott helyzet és időpont dönthet a követendö AKTUÁLIS PRIORITÁSI SORREND felöl.

\section{A területfejlesztés jövőképe}

A területi politikának a felvázolt alapvetỏ célkitủzéseket az adott gazdasági és társadalmi feltételek mellett kell követnie. Az indító helyzetet számos erősség és gyengeség, valamint lehetőség és veszély jellemzi.

$\mathrm{Az}$ összes meghatározott tényezőnek a figyelembevételéböl az a következtetés vonható le, hogy az elkövetkezendő egy-két évtizedben a gazdasági tevékenységek telepítésében és a népesség letelepedésében nem valószínü, hogy történnek radikális területi változások. Az átalakulási folyamatok többé-kevésbé a jelen térszerkezetben fognak végbemenni. A térszerkezet fejlesztése ezért nem számíthat nagyarányú regionális változásokra (bár kisebb interregionális vándorlást, különősen a korábban erősen iparosodott vagy a túlnépesedett mezőgazdasági területeken nem lehet kizárni), azonban a kisebb régiókban számolni kell a (mikro) strukturális és foglalkoztatási változásokkal, és a meglévő adottságok megújitásával.

A VISION térségben a teruleti politika legfontosabb célkitüzései a tevékenységek különböző területein valósítandók meg:
A) A térszerkezet fejlesztése.
B) A városok fejlődési irányai. 
C) A vidéki térségek fejlesztése.

D) A kőzlekedés és a telekommunikáció fejlesztése.

E) Környezetvédelem, a természeti és kulturális örökség kezelése.

\section{A) A térszerkezet fejlesztése}

A gazdaság és társadalom térszerkezetének fejlesztése alatt azokat a széleskörü intézkedéseket értjük, amelyek a városi és vidéki térségekre, illetve az infrastrukturális hálózatokra egyaránt hatással vannak. A meglévó korlátokat és feltételeket figyelembe véve a térszerkezet fejlesztésének öt fô feladatra kell koncentrálni:

- A város és vidék új kapcsolatának kiépítésére.

- A növekvő regionális egyenlőtlenségek kezelésére.

- A periférikus helyzet kezelésére.

- A regionális gazdasági szerkezet diverzifikációjára és az endogén erőforrások mobilizálására.

- $\mathrm{Az}$ információ és a tudás jobb elérhetőségének megteremtésére minden térségben.

\section{A.1) A város és a vidék új kapcsolatának kiépitése}

A keleti VISION országokban a város és vidék dichotómia a múltban is, a jelenben is hagyományosan nagy ellentétpár. Történelmi szempontból a városi és a vidéki települések kőzőtt hatalmas volt a társadalmi, számos esetben pedig az etnikai összetételből adódó távolság. A fejlettségben, a foglalkoztatásban, a jövedelmekben, az oktatásban és a kommunális szolgáltatások fejlettségében a városi és a vidéki telepưlések közőtt jelentős volt a különbség, amely részben még ma is fennáll. A növekedés és az innováció terjedése a városból a falura nem volt olyan organikus $\mathrm{s}$ egyben folyamatos, mint Európa nyugati felében.

A város és vidék sikertelen integrációjának az egyik legfontosabb oka a kisebb kőzpontok ${ }^{4}$ elégtelen fejlesztési és vonzási potenciálja. A kisvárosok száma és sủrüsége lényegesen alacsonyabb, fejlettségi szintjük pedig csekélyebb, mint a nyugati VISION országokban (Ausztria, Németország, Olaszország). A fejlesztési erőfeszítések és források a nagy városokban, a közigazgatási, ipari központokban koncentrálódnak. Vannak olyan térségek, amelyek nem rendelkeznek megfelelő szolgáltatási ellátási központtal, és nincsenek kapcsolódási pontjaik a fejlesztési interakciókhoz.

${ }^{4}$ A kisebb központok fogalma nem azonos a városok méretével. A kisebb térségek azon központjaira utal, amelyek naponta elfogadható utazási idôn belül elérhetők. A különböző elérhetóségi és utazási lehetőségeket figyelembe véve e térségek mérete országonként eltérỏ lehet. 
Politikai lehetőségek:

- A fejlesztési politika súlyát és hangsúlyát a kis központokra, és azok fejlesztésére kell forditani. Ezeknek a centrumoknak kell betölteniük a strukturális átalakulás szervezésének szerepét nagyobb arányú lakóhely-változtatások nélkül. A kis és középes méretü központok hálózatait úgy kell fejleszteni, hogy az adott ország területének egészét, és a szomszédos országok határ menti térségeinek központjait is lefedjék. Olyan megfelelö centrumokra lenne szükség, amelyek mindenhonnan elfogadható időn belül elérhetók.

- Jelentős mértékben javítani kell a központok és környezetük közötti utazási és szállítási lehetóségeket. Ezekben az országokban a kisebb régiókon belüli közlekedési hálózatoknak a transz-európai hálózatokhoz hasonló prioritást kell biztositani. A tömegközlekedésnek fontos szerepet kell betöltenie e hálózatokban.

- A tervezés során, a vidéki településeken lehetỏséget kell teremteni az ủj farmereknek a gazdasági tevékenység végzésére. Ugyanakkor megfelelö életkörülményeket kell biztosítani a nem mezőgazdaságból élōk egyre nagyobb számának, akik a városi élet helyett a természethez közeli, de a szolgáltatások tekintetében városi ellátást biztositó életet választják. A vidéktervezési szabályozásnak és gyakorlatnak sokkal differenciáltabbnak és rugalmasabbnak kell lennie, de ugyanakkor sokkal konzekvensebbnek is a vidéki települések örökölt kulturális értékeinek megóvását illetóen.

- A kis központoknak a nagyobb városokkal és a közigazgatási centrumokkal szemben méltányos és egyenló elbánást kell élvezniük a jövedelmek szabályozásának, illetve a kormányzati segélyek és támogatások elosztásának terén is. Ugyanakkor a központi településeknek magasabb szintü szolgáltatásokat kell nyújtaniuk környezetük számára, és a megfelelō vonzáskörzetükben nekik kell levezényelni a gazdaság fellenditésével és a szerkezetváltással kapcsolatos feladatokat. A helyi önkormányzati finanszirozásnak figyelembe kell vennie ezt a város-vidék szimbiózist. Megfeleló igazgatási és finanszírozási megállapodásokat kell alkalmazni annak érdekében, hogy a kisebb központok e regionális szerepét figyelembe lehessen venni.

\section{A.2) A növekvő regionális egyenlötlenségek kezelése}

A múltban a keleti VISION országok alapvető területi egyenlőtlensége a városi és a vidéki térségek és települések között húzódott. A városok és a régiók közötti különbségek sokkal mérsékeltebbek voltak. A tervgazdaság körülményei között mindenuitt egyenló árak és bérek - az egyenlötlenség legfontosabb eleme az iparosodottság foka volt, ezért a tervezési hatóságok célja a legfontosabb regionális egységek közötti viszonylag egyenletes iparosodottsági szint elérése volt. Ezek az erőfeszítések többé-kevésbé sikeresek voltak, legalábbis a foglalkoztatást tekintve. $A$ politikai és a gazdasági változásokat követöen a városok illetve a régiók közötti különbségek növekedni kezdtek. Felszinre kerültek a földrajzi elhelyezkedés előnyei 
és hátrányai csakúgy, mint a vállalkozási és a piacgazdasági tapasztalatok rejtett, hagyományos különbségei. Az egyes városokra és régiókra a - belföldi és kullföldi - piaci erők eltérỏ hatással voltak. Az egyenlőtlenségeket tovább erósítette a külföldi közvetlen beruházások szelektív letelepedése is. Amióta az egyenlőtlenségek a piaci erők kiteljesedésével és a kullföldi közvetlen beruházások növekvő arányával párhuzamosan növekednek, a különbségek az átmenet magasabb fokán álló országokban egyre inkább láthatóvá válnak, míg a többi országban, a jövőben kell számolni az egyenlötlenségek növekedésével.

A növekvő egyenlötlenségek nem csak azt jelentik, hogy a régiók közötti különbségek szélesednek. Magóval hozza a régiók közötti rangsor és relatív pozíció alapvetó megváltozását is. Vannak viszonylag fejlett helyzetben lévő régiók, míg más, hajdan jobb pozíciójú régiók helyzete jelentős mértékben romlott. Természetesen a területfejlesztés ennél jóval komplikáltabb: vannak olyan régiók, amelyek az átmenet évei alatt már többször is változtatták pozíciójukat. Ezen fenntartások figyelembevételével a következő régiótípusok fedezhetők fel a VISION térségben:

- A megszilárdult teljesitményũ és poziciójú régiók és városok. Általában a fövárosok, fontos kikötök és néhány, a fỏ infrastrukturális folyosókhoz, illetve az EU határhoz közel fekvö térség és régió. E térségekbe települt a külföldi közvetlen befektetések legnagyobb része és a szolgáltatások legdinamikusabb fajtái (bankok, biztosítók, üzleti szolgáltatások, reklám, új kereskedelmi formák, média stb.). Az egész nemzetgazdaság érdekelt e térségek fejlesztésében.

- A hajdan különleges pozíciójú, de most sokkal rosszabb helyzetben lévó régiók. Főleg a bányászat és a nehézipar régiói, amelyek most számos szerkezetátalakítási problémával néznek szembe. Ezek a problémák, bár hasonlóak a nyugati hanyatló ipari régiók problémáihoz, különböznek is azoktól. Különböznek abban, hogy az ipari munkások nagy része még mindig a vidéki térségekben él, vagy nemrég költözött csak fel vidékröl, ezért megfigyelhetö az a tendencia, miszerint - ezen emberek elsődleges elbocsátásával - elodázzák a probléma megoldását, és az ipari szerkezetváltás kihivását vidéki munkanélküliséggé konvertálják.

A legtöbb vidéki térség helyzete romlott az elmúlt évtizedben, bár a vidéki térségek fejlesztése is igen különbözö. A helyzetért a leginkább felelós tényezök közuil a romló pénzügyi feltételek és a mezógazdaságban tapasztalható növekvó verseny sorolható az elsỏ helyre. Sok keleti VISION országban a második fó tényezó a hosszan tartó bizonytalanság, és a földtulajdon és fơldhasználat körüli zürzavar. A harmadik tényező pedig az volt, hogy a vidéki térségeket az ipari recesszió legalább olyan komolyan érintette, mint a hagyományos ipari térségeket. Ennek oka részben az ipari válságterületekről visszaköltöző lakosság, amelynek eredményeként néhány országban a már eleve magas mezőgazdasági munkanélküliség az elmúlt évtizedben még tovább növekedett. 


\section{Politikai lehetőségek:}

- A vezetö és dinamikus régiók fejlödését nem szabad meggátolni vagy lelassitani, sổ a kormányzatnak támogatnia kell ôket. A támogatásnak azonban nem az üzleti szféra pénzügyi szubvencióját és segitését kell jelentenie, hanem a városi területek és az infrastrukturális lehetôségek biztositását.

- A hanyatló ipari térségek kormányzati és nemzetközi segitséget igényelnek, leginkább az infrastrukturális beruházások és a dinamikus iparágak általi munkahelyteremtés formájában. E térségekbe települö külföldi beruházásokat bizonyos szintủ támogatásban és engedményben kell részesíteni. Támogatni kell a már meglévő infrastruktủra felújitását és ủjrahasznositását.

- Hosszú tóvon a regionális politikát készitoóknek elsősorban a hatalmas vidéki térségek átalakitảsára kell fókuszálniuk eröforrásaikkal. A prioritások egyike az infrastruktúra fejlesztése és az elérhetőség javitása. A másik prioritás a kisés középvállalkozások támogatásával történỏ diverzifikált gazdaságszerkezet kialakitása és fejlesztése.

\section{A.3) A periférikus helyzet kezelése}

A VISION térség nagy része Európa középső részén helyezkedik el, így a régió közelebb fekszik az európai metropolisz-központhoz, mint egyes EU régiók. $A$ térségben a periférikus helyzet nem földrajzilag determinált, sokkal inkább a történelmi, politikai és gazdasági fejlödés következménye.

A VISION térség keleti felét a vasfüggöny évtizedekig elszigetelte Európa többi részétől, ezért nem lehetett részese sem az integrációs folyamatnak, sem annak a politikai, kulturális, gazdasági és technológiai haladásnak, amely kialakította a kontinens nyugati felének jelenlegi gazdasági és társadalmi szerkezetét. A fejlödés következményeként a keleti VISION térség, mint egész, sok tekintetben periférikus jegyeket mutat.

A VISION térségben $16000 \mathrm{~km}$ hosszú szárazföldi határ található. A VISION térségnek több mint 60\%-a tekinthető határ menti térségnek (mind terület, mind népesség tekintetében). Az országhatárok hossza a VISION térségben az elmúlt évtizedben $50 \%$-kal növekedett. A határmentiség ezekben az országokban évtizedeken át periférikus helyzetet jelentett.

A periférikus helyzet nem csak a határátkelök számától és kapacitásától fuggg. Amennyiben a határ két oldalán egészen más szabályozások, kölcsönösen nem átváltható valuták, ártorzulások és korlátozások sokasága uralkodik egy bizonyos időszakban, akkor a csempészet és a feketekereskedelem sokkal jobban prosperálhat, mig a kölcsönös és fenntartható partneri kapcsolatok nem fognak fejlödni.

A fejletlen közlekedési hálózat, vagy az alulfejlett városhálózat következményeként - a határ menti perifériák mellett - viszonylag nagy , belsô perifériák" találhatók az országokban. A térségek nem rendelkeznek olyan városközpontokkal, amelyek elfogadható távolságon belül megfelelö szervezőerővel és szolgáltatáskinálattal rendelkeznének, sőt az ország más részeiböl is csak nehezen megközelíthetok. 


\section{Politikai lehetöségek:}

- A határ menti régiók periférikus helyzete jelentös mértékben csökkenthetö a határok "megnyitásával", ủj határátkelök létesitésével, a határon átnyúló kapcsolatok bövitésével, a határátlépési procedúra egyszerüsitésével, illetve az áruk, a töke és az emberek határokon keresztüli mozgását akadályozó politikai, gazdasági és fizikai korlátok lebontásával. A városok felújithatják kapcsolataikat környezetükkel, és a hazai agglomerációjuktól távol esö térségek ujj piacokat találhatnak a határokon túl.

- A határ menti térségekben a fenntartható kapcsolatok megteremtésének legjobb megoldása az európai integráció, amely orvosság a VISION térség egészének periférikus helyzetére is.

- A "belsö perifériákat" a regionális illetve a vidékpolitika egészének keretében kell kezelni. A városhálózat és a közlekedési hálozat fejlesztése folytán e térségekre különös figyelmet kell fordítani.

A.4) A regionális gazdaságszerkezet diverzifikációja, és az endogén eröforrások mobilizálása

A központilag irányitott tervgazdálkodás csak nagy egységekben volt képes gondolkodni. A keleti VISION országokban a politikai változásokat megelözően alig léteztek kis- és középvállalkozások. Egy város gazdasági fejlődését egy-két nagy ipari vállalat jelentette, amelyek egy vagy kis számú termék gyártására specializálódtak. Számos esetben ez az egy vagy néhány gyár biztositotta a munkalehetóséget, a pénzügyi eröforrásokat és a szolgáltatásokat az egész város számára. A politikai és gazdasági átmenet éveiben az ipari válság, az iparvállalatok csődje az egész város számára drámai helyzetet teremthetett. Ugyanakkor a vidéki területek nagy részére a monokultúrás mezögazdaság volt jellemzö.

A diverzifikáció legfőbb eszköze a kis- és középvállalkozások támogatása és segítése, hiszen azok eltérő profilja és tevékenysége a legjobb garancia a régiók és városok gazdasági bázisának stabilitására. Egy régió kis- és kőzépvállalkozásai egymással együttmüködve közös tevékenységekre és ügyletekre fognak vállalkozni. Ók képesek az endogén fejlődés alapjának megteremtésére. Úgynevezett „klasztereket” hoznak létre, ahol a fejlödés és a növekedés kölcsönös pozitív interakciókra és a kooperációs hálózatokra helyezödik. Ezek a hálózatok biztonságot nyújtanak egy adott szektor ingadozása vagy válsága esetén.

A regionális gazdasági szerkezet és az endogén erőforrás-felhasználás diverzifikációjának elérésében a legcélravezetőbb út a területfejlesztési és tervezési célkitüzések, intézkedések kombinálása, összekapcsolása és harmonizálása. A vidékfejlesztési politikák és a természeti örökség megörzése, a városfejlesztési politikák és a kulturális örökség védelme, a városszerkezet alakitása és a területi egyenlötlenségek kezelése kölcsönösen függenek és kiegészítik egymást, egy sokkal diverzifikáltabb és fenntarthatóbb térszerkezetet eredményezve. 
Politikai lehetöségek:

- Stratégiai politikai cél a városok és a régiók gazdasági szerkezetének diverzifikációja. A regionális fejlesztési politika eszközrendszerének megfelelö átalakitásával ezt a sokszinúbb gazdasági szerkezetet ösztönözni kell a kis- és középvállalkozások irányába is.

- Szükség van a közvetlen külföldi befektetésekre, azonban önmagukban nem elegendők egy város gazdasági bázisának megalapozására. Akkor van igazán pozitiv hatásuk, ha nagy számú hazai beszállitó vesz részt a termelési folyamatban. A kormányzatoknak és a helyi önkormányzatoknak programokat kell kezdeményezniük a transznacionális gazdasági egységek és a helyi, regionális kis- és középvállalkozások közötti beszállitói kapcsolatok kiépitésére.

- A gazdasági szerkezet diverzifikációja elsődleges cél, nemcsak az „egy gyár, egy város" esetében, de a vidéki térségek számára is. A mezögazdaság korlátozott kapacitását figyelembe véve csak egy diverzifikált gazdasági struktúra biztosithatja a térségek fenntartható fejlödését. A vidéki turizmus és rekreáció fejlesztése a vidéki foglalkoztatás és jövedelem javitásának fontos tényezöjeként szolgálhat.

- Elsó lépésként meg kell határozni azokat a helyi rendszereket, amelyek köré felépithetỏ egy integrált gazdasági és társadalmi stratégia. Eröteljes tudástranszfert kell kialakitani az önszervezö rendszerek helyi fejlesztésére és tervezésére. Ezért a regionális gazdaságpolitikának szigorúan integrálódnia kell a többi releváns politikába.

A.5) Az információ és a tudás jobb elérhetöségének megteremtése minden térségben

A VISION országok már az elmúlt évtizedekben is azon országok közé tartoztak, amelyekben magas volt a népesség képzettségi szintje. A tudományos kutatási, kulturális és müvészeti lehetőségek viszonylag magas költségvetési allokációt élveztek. A politikai rendszer megváltozása ủj - pénzügyi és strukturális - akadályokat és nehézségeket hozott.

Az oktatási rendszer természetesen továbbra is a tudás és az információ elsődleges forrása. Az oktatási intézmények területi és települési környezetben müködnek, ezért az oktatási és a területi politikákat egymással össze kell hangolni:

A vidéki népesség csökkenése miatt elkerülhetetlen a vidéki iskolahálózat bizonyos mértékü konszolidációja. Ennek során azonban figyelembe kell venni, hogy az iskolák - a vidéki térségekben - nem csak oktatási lehetóséget nyújtanak, hanem a falvakban az intellektuális és kulturális élet központjai is egyben.

A középfokú oktatás és a szakképzés az átalakulás és a foglalkoztatás szempontjából elsödleges fontosságú. Míg a gazdaság igényeihez igazítjuk, a specializálódást nem lehet az aktuális kereslethez képest túl szükre szabni - különösen a vidéki térségekben -, mert az nehezítené a jövőbeli átalakítást.

A felsöfokú oktatási intézmények az oktatás mellett a kutatás-fejlesztés, és a tudományos élet fontos központjai. Ezért minden nagy régióban indokolt ezen köz- 
pontok létrehozására vonatkozó igény. Másrészt néhány VISION országban a felsőfokú intézmények túlságosan kicsik és szétaprózottak a szellemi potenciál, az információ és a kutatási infrastruktúra kapacitásának hatékony kihasználására. A szervezeti konszolidáció emiatt ésszerủ lenne, azonban nem jelentene szükségképpen területi centralizációt.

A kultúrának és az információnak fontos szerepe van a nemzeti, regionális és helyi identitás megőrzésében és erösítésében is. Ezért a helyi és regionális média (újságok, TV, rádió) és a regionális kulturális és oktatási intézmények kiemelkedö jelentöségúek. Különösen fontosak a VISION térségben élö nemzeti és etnikai kisebbségek számára.

A modern információs technológiáknak különleges jelentőségük van a tudás és információ elérhetőségének biztosításában. Ezek a technológiák és lehetőségek teljesen új eredetűek, ezért a történelmi fogyatékosság nem játszik olyan szerepet, mint más infrastruktúrák esetében. A kései indulás azt az elönyt is magában hordozhatja, hogy a legújabb eredmények, rendszerek és technológiák alkalmazhatók a különbözö hálózati rendszerek létesítésekor (pl. Internet).

$A z$ elözö politikai rendszer alatt magas prioritást kapott a $K+F$, föként a tudomány területein és bizonyos speciális ipari ágazatokban. $\mathrm{Az}$ átmenet alatt a $\mathrm{K}+\mathrm{F}$ a szükösebb állami források és a kutatók tömeges kivándorlása, illetve a magán szektor alacsony szintú beruházása - beleértve a $\mathrm{K}+\mathrm{F}$-be történő közvetlen külföldi befektetéseket - miatt jelentősen lecsökkent. Mostanában a rendelkezésre álló $\mathrm{K}+\mathrm{F}$ kapacitások elönyeit egyre inkább felismerik. Még mindig hiányosak azonban az üzleti vállalkozások és a helyi illetve regionális kutató bázisok közötti interakciók.

$\mathrm{Az}$ új képességek fejlesztése iránti igény egy jövőbeli megfontolás tárgya, csakúgy, mint a központ gazdasági tevékenységéhez integrálódó vidéki térségek gazdasági és társadalmi problémái. E feladat legfontosabb eleme az új felhasználások és szolgáltatások potenciáljának ,tudatos növelése”.

Prioritást kell adni az olyan regionális akcióknak, interregionális együttmúkődéseknek, mint a teleworking, távoktatás, egyetemi és kutatókơzponti hálózatok, KKV-k részére történỏ telematikai szolgáltatások, valamint városi információs szupersztrádák. Ebben az értelemben a közösségi szektor, beleértve az egyetemeket és a magán szektort, illetve a társadalmi szervezetek közötti partneri szerepet, különösen fontos.

A határon átnyúló együttmüködéseket is fel kell használni a tudás és az információ jobb elérhetőségének biztosítására. A szomszédok nyelvének oktatása, a diákok, hallgatók és tanárok csereprogramjai, és a kutatás területén megvalósuló együttmüködés is e célokat szolgáló eszközök és intézkedések.

\section{Politikai lehetöségek:}

- Az oktatási rendszer ủjjászervezése és fejlesztése során jobban figyelembe kell venni a területi tényezöket. A településhálózat és térszerkezet korlátozza a központositási lehetöségeket, és az ésszerüség határait átlépõ tủlzott specializációt. 
- A tudás és az információ elérhetôségének támogatásában nagy jelentőséget kell tulajdonitani az új információs technológiai találmányoknak.

- Tảmogatni kell a helyi és regionális szintü információ előállitiását és terjesztését a helyi szintủ identitás és demokrácia támogatása érdekében. A nemzeti és regionális kormányoknak egy igazságos támogatási rendszert kell kidolgozniuk e tevékenységek számára.

- Támogatni kell helyi és regionális szinten a meglévō kutatóbázisok és üzleti vállalkozások közötti kapcsolatokat és interakciókat. Az innovativ termékek világpiacra való bevezetése érdekében prioritást kell kapnia a kutató központok és a kis- és középvállalkozások „inkubátorai” közötti integrált hálózatok megvalósitásának.

- A Nemzeti Információs Társadalom Stratégiáknak és a hozzájuk kapcsolódó akció terveknek többek között olyan fejezeteket kell tartalmazniuk, amelyek különösen az ICT infrastruktúrák felfejlesztésének területfejlesztési aspektusai$r a$, és az ICT-knek a kulturảlis és nyelvi diverzifikáció védelmében való felhasználására vonatkoznak.

- A regionális és központi kormányzatoknak támogatniuk kell a fejlett telekommunikációs szolgáltatások érdekében történő infrastrukturális fejlesztéseket az olyan szervezetek részére, mint egészségügyi intézmények, iskolák, könyvtárak. A támogatás során együtt kell müködni az intézmények fenntartóival, és elhelyezkedésüktöl függetlenül kell támogatásban részesiteni öket.

\section{B) A városok fejlödési irányai}

Évszázadok óta az európai városok azok a helyek, ahol a dolgok történnek, helyet kap az emberi tudomány, a kultúra és a technológia haladása, és ahol megszületett a demokrácia. A helyzet többé-kevésbé ma is ugyanez, bár az információs és telekommunikációs technológia lecsökkenti a hely és a távolság szerepét az emberi kommunikációban.

A VISION térségben a városok ugyanezt a szerepet játszották. Néhány sajátosság azonban speciálissá teszi a városfejlesztési stratégiát e térségben.

\section{B.1) A fejlesztés prioritásai}

Míg a II. világháborút megelözően a legtöbb VISION ország városfejlesztési politikáját a fỏváros centrikusság jellemezte, addig a hatvanas, hetvenes és nyolcvanas években a fejlesztés közvetlenül a második szinten elhelyezkedő városokra irányult. A városfejlesztés e prioritásrendszere a középméretư városok viszonylag erốs csoportjának kiemelkedését tette lehetővé. A városok fejlödésében döntõ szerepet játszottak a közigazgatási funkciók. A legtöbb ủj ipari beruházás a közigazgatási központokba települt, és itt valósult meg az állami lakásépítések nagy része is. Minde-

5 Szulkséges annak hangsúlyozása, hogy a „középméretủ városok” különböző méretủek lehetnek az adott ország méretétől és telepủléshálózatától fủggỏen. 
mellett csőkkent a fővárosok nyomasztó túlsúlya, és egy kiegyensúlyozottabb városhálózat jött létre.

Nyilvánvalóan voltak olyan városok, amelyek számára hátrányokkal járt ez a fejlesztési stratégia. Elöször is hátrányos helyzetben voltak a központi közigazgatási funkcióval nem rendelkezó városok. Összehasonlíthatatlanul kevesebb esélyük volt a fejlesztésekre és az állami támogatásokra, mint a közigazgatási centrumoknak, ahol az állam és a párthatalom koncentrálódott. A városi migráció többsége a kőzigazgatási centrumok felé irányult, míg a tőbbi város nagy részében csőkkent a lakosság. Bizonyos szempontból vesztesek voltak azok a városok is, amelyek nem illettek bele az átlagos közigazgatási centrum keretébe. A közigazgatási térségükön - és néha az országhatárokon - túlnyúló vonzáskörzettel és vonzerővel rendelkező városok ebben a rendszerben nem voltak képesek a nem egységes funkciók kibontakoztatására. Lengyelországban Krakow, a Cseh Köztársaságban Brno, Ukrajnában Lvov és Chernivci, a volt NDK-ban pedig Lipcse és Drezda tartozik ebbe a várostípusba. Végül az európai jelentőségü fơvárosok is vesztesei voltak ennek a politikának, hiszen Európa többi centrumától elszigetelve, egy kis állam helyi életére kényszerítve messze estek az európai gazdasági és kulturális fejlődés fỏ áramlataitól. Ez a térség valamennyi fövárosára igaz, de különösen drámai Berlin esetében.

Azonban vitatható volt a politika nyerteseinek haszna is: a nehézipari telephelyek és a nagy, egyhangú lakótelepek - a városfejlesztés legföbb eredményei - ma problémás térségként szerepelnek, ahol roppant szorongató kérdés a modernizáció, a fenntartás, illetve a környezeti és társadalmi helyzet javítása.

\section{Politikai lehetőségek:}

- A területfejlesztés célkitũzéseivel és a városok e csoportjának diszpreferált helyzetével összhangban, elöször a kisvárosok fejlódését kell biztositani, és egy kiegyensúlyozottabb struktúrájú városhálózatot kell kialakitani.

- A közép- és délkelet-európai fơvárosok és a második szinten elhelyezkedö városok néhány speciális funkcióra koncentrálva részt vesznek a nemzeti határokon átnyúló munkamegosztásban. A specializáció néhány jellemzôje már megjelent, mig a többi az újabb integrációs kapcsolatok során fog kialakulni.

- A nemzeti szintü funkciók és intézmények több város közötti megosztása országokon belül is megtörténhet. A keleti országokban ezt nem nagyon alkalmazták eddig, azonban Németországban, valamint kisebb mértékben Olaszországban már évizedek óta bevett gyakorlat. Mindemellett vannak olyan keleti VISION térségbeli városok, amelyek képesek lennének átvenni nemzeti funkciókat.

- A térség társadalmi-gazdasági egyensúlyának elérése érdekében támogatni kell a tengerparti - különösen az adriai - térségek és városok, valamint a hátországok illetve a határon átmyúló együttmüködések kapcsolatrendszerének, hálózatának kialakulását.

- A különbözõ városi funkciók hatékonyságának teljesebb meghatározása érdekében célszerü definiálni az egyes városok erösségeit, és megteremteni egy bizonyos fokú (nemzeti és nemzetközi) munkamegosztást. Ez nem csak a fôvárosokra igaz, hanem a városhálózat többi szintjére is. 
- Az általában túlságosan hierarchikus és egységes rendszert diverzifikáltabbá, több központúvá és differenciáltabbá kell alakitani.

\section{B.2) A belsö városszerkezet átalakítása}

A keleti VISION országokban a jövő egyik legnagyobb kihívása a városok belső szerkezetének átalakítása. Ezeket a struktúrákat a múltban a következók jellemezték:

- A hagyományos belvárosi részeket évtizedek óta elhanyagolták. Ha történt is rekonstrukció a belvárosban, az a régi épületek lebontását, és új, a hagyományos környezethez nem illö épületek emelését jelentette. A belvárosok régi lakásállomảnya nem került felújításra, minőségük és komfort fokozatuk leromlott. A tipikus belvárosi funkciók, mint kereskedelem, szórakozás, bankok, pénzủgyi szolgáltatások, idegenforgalmi lehetőségek vagy egyáltalán nem léteztek, vagy csak alsóbbrendü szerepüek voltak.

- Az ủj lakóházak épitése többnyire a városok külső kerületeiben valósult meg, mégpedig általában elöre gyártott elemekbỏl összeállított hatalmas monofunkcionális lakótelepek építésével. Ezáltal a hagyományos lakásoknál többnyire nagyobb komfortot kínáltak, azonban már rögtön felépítésük után jelentkezett néhány komoly probléma: funkciójuknak nem feleltek meg, kis alapterület, szigetelési problémák, gyenge infrastruktúra és szolgáltatás stb.

- A lakónegyedek városi terjeszkedése eltérö módon alakult. Míg a nyugati VISION országokban, valamint Szlovéniában, Horvátországban és Magyarországon jellemző volt a városok terjeszkedése, addig más országokban korlátozták azt, vagy más formában valósult meg. Azonban a felépült nyaralók, és a kialakitott „hobbikertek" a viskókkal néha nagyobb területeket foglaltak el, mint a városi lakónegyedek.

A politikai változásokat követően jelentősen megváltoztak a városok szerkezetét alakító tényezỏk és velük együtt a kihívások, amelyekkel a várostervezés szembenéz.

A gazdasági változások következményeként magukhoz tértek a városközpontok és a belvárosi területek. Lengyelországban, Magyarországon, Romániában és Bulgáriában az üzletek és kiskereskedések száma négy év alatt (1990 és 1994 között) több mint a kétszeresére emelkedett. Ezek leginkább a városközpontokban találhatók. Az új kereskedelmi bankok a városközpontokban építették fel igazgatóságaikat, és nyitották meg fiókjaikat, amelyek ma hozzájárulnak e városok képéhez. Rengeteg új szálloda épült. A belvárosi területek épületeit felújították, a lakófunkciót felváltotta az üzleti funkció. Azonban érzékelhetök a városközpontokra negatív hatással járó folyamatok is: a külvárosokban felépült bevásárló és szórakoztató központok, multiplex mozik a városközpontok üzletei felől maguk felé csábítják a vásárlókat és fogyasztókat.

Az elmúlt évtizedekben felépült hatalmas lakótelepek igen fontosak. A merev technológia miatt a lakásokat nem lehet újjáépíteni vagy kibövíteni. A fütési költségek gyorsan emelkednek. A szủkséges technológiai felújítás idejének közeledtével egyre nagyobb lesz a megfelelỏ és hatékony felújítási technológiák hiányának nyomása. 
Megindult a társadalmi szegregáció, a magasabb jövedelmủek elhagyják ezeket a lakótelepeket, és vagy a belvárosban keresnek lakást, vagy az azt körülölelö családi házas zónában. Az alacsonyabb jövedelmú csoportok pedig beköltöznek a lakótelepekre. A keleti VISION országokban (beleértve a volt NDK-t is) körülbelül 17 millió ember, azaz a népesség közel $20 \%$-a él ilyen nagy lakótelepeken, a nyugati VISION országokban néhány százezer.

Elörelátható, hogy a közeli jövőben a legtöbb keleti VISION országban tovább fog folytatódni a városok terjeszkedése. A magánlakás építésre vonatkozó korlátozások megszuintetése és a városi migráció elkerülhetetlenül erősíteni fogja ezt a folyamatot. A városfejlődési folyamatot a szuburbanizáció és a városi agglomerációk kialakulása fogja jellemezni, amely sokkal erősebb lesz, mint a múltban volt.

A várostervezés jelentős kihivásokkal néz szembe az átmenet idöszakában. Különösen ott komolyak a nehézségek, ahol a városi területek és ingatlanok rehabilitálása a soron következő feladat. A tulajdonosi kapcsolatok gyakran nem tisztázottak, a nyilvántartás nem képes lépést tartani a privatizációval. A városi hatóságok nem rendelkeznek olyan ingatlanok és pénzösszegek felett, amelyekkel az ingatlanpiacot befolyásolni tudnák, jogaik és kompetenciáik nem tisztázottak teljesen. A szabályozások végrehajtása időigényesebb és bonyolultabb, mint a múltban volt. A legtöbb régi városterv már nem sokat ér, újakat pedig nehéz kidolgozni a nem teljesen tiszta helyzet miatt.

\section{Politikai lehetőségek:}

- A belvárosokat úgy kell felújitani, hogy lehetöleg megörizzék eredeti képüket és stílusukat (város rehabilitáció). Indokolt a lakófunkció megórzése is. Gondoskodni kell a zöldövezetekrôl és a közlekedési sávokról. Szigorúbban kell ellenörizni az új bevásárlóközpontok (,márkaüzlet-központok") és gyáregységek (factory outlet) letelepedését.

- A hatalmas lakótelepek átalakitása és alapos felújitása elsőbbségi kérdés. A lakásokat megfelelö ủj technológiákkal (az elsö feladat a höszigetelés) fel kell ủjitani. E területeken új szolgáltatásokat, szórakozási lehetõségeket kell biztositani, üj munkahelyeket kell teremteni (a demográfiai változások miatt hosszabb távon feleslegessé váló bölcsõdék, óvodák és általános iskolák átalakitásával). Növelni kell a zöld területeket. A lakótelepek hasonló struktúráját és jellemzöit figyelembe véve a már meglévö nemzetközi tapasztalat- és technológiacsere különösen hasznos lehet, ezért szükséges azok élénkitése.

- A várostervezés és politika feladata a városi területek növekedésének ellenörzése és irányitása, amit az elővárosok fejlesztése során megfelelõ területek kialakitásával és rendelkezésre bocsátásával lehet megoldani, egyben figyelembe kell venni a szabad és a mezõgazdaság számára értékes területek védelmét is. Míg az általános adminisztrativ tiltásokat meg kell szüntetni, a tervezett és szabályozott fejlesztés megelözhetné a túlzott városi terjeszkedést, és megóvhatná a beépitetlen zöld területeket.

- Az illegális épitkezések esetében be kell tartatni az épitési szabályozásokat. Különös figyelmet kell forditani a szabályellenes letelepülésekre, amelyek a 
háborủs térségekböl vagy a szegényebb régiókból való népességmozgás következményeként jönnek létre. Ez azonban csak akkor lehet eredményes, ha bevezetik vagy megerôsitik a szociális lakásépitést és a szociális lakáspolitikát.

- A várostervezési módszereket és eljárásokat újra kell szabályozni. Támogatandó a telekkömyvezés rendszerének modernizálása. A földre, épitkezésre, lakásra, környezetre és más fontos kérdésre vonatkozó irányadó eszközöket, azok törvénybeillesztésével együtt üjra felül kell vizsgálni.

\section{B.3) Városi lakásépités, városfinanszírozás, városi szolgáltatások}

A lakáspolitika a városfejlesztés egyik kulcskérdése. Az állami szociális lakásépítések száma sok országban meredeken csőkkent, vagy gyakorlatilag megszünt. Ugyanakkor az állami tulajdonban lévó lakásokat bérlöik privatizálták. Bulgáriában, Horvátországban, Magyarországon és Romániában a lakások több mint 90\%-a magántulajdonban van, ami magasabb, mint bármely nyugat-európai országban. A városi lakásokat azért privatizálták, mert sem az állam, sem a helyi önkormányzatok nincsenek abban a helyzetben, hogy az állami tulajdonú lakások müködtetését és helyreállítását tovább támogassák. A lakásbérleti dijakat nem lehetett olyan magas szintre emelni, amely szükséges lett volna a kiadások fedezéséhez. Azonban továbbra is veszélyt jelent, hogy az új tulajdonosok (a volt bérlók) szintén képtelenek nagyobb összeget fordítani a felújitásra és modernizációra. Az ilyen esetekben a városi lakásállomány jelentős része elértéktelenedésre és pusztulásra ítéltetett. A másik kérdés a mobilitás. A tulajdonlás dominanciája, a házak kủlönbơző formája és típusa miatt, illetve mivel a jelzálog rendszert még csak most kezdik bevezetni, a lakásbérletnek hiányzik az alternatívája. Ezért a mobilitás tulajdonképpen minden esetben a lakások/házak vételét és eladását jelenti, ami lassú, drága és komplikált mobilitást eredményez.

A mennyiségi hiány mellett komoly probléma a lakások minöségi állapota is. Mind a meglévő állomány modernizációja és felújítása, mind a lakások méretszerkezetének javítása igen fontos és égető kérdés - mivel a lakások túlnyomó tőbbsége kicsi, akár a vidéki térségeket, akár a háború után épült lakótelepeket nézzuk.

Számos országban a lakásállomány, a kommunális infrastruktúra és a kulturális intézmények csőkkenő, de még mindig jelentős része van nagy állami, vagy hajdani állami vállalatok tulajdonában. Ez természetesen korlátozza a lakások és szolgáltatások finanszírozásának terhét viselő vállalkozások versenyképességét. Továbbá, talán még a lakástulajdonnál is komolyabban korlátozza a munkaeró mobilitását, mivel a lakókat nem csak a város kőti, hanem a vállalat is, mely a lakás tulajdonosa.

A helyi ơnkormányzatok kétféle funkciót teljesítenek. Egyfelől az állam ügynökeként járnak el, amikor végrehajtják a központi és/vagy regionális parlamentek és kormányok által elrendelt feladatokat (néhány adminisztratív funkció, alapfokú oktatás), másfelöl pedig helyben, saját hatáskörben eldőntőtt feladatokat és fejlesztéseket végeznek. A csak a helyi bevételekre tơrténő támaszkodás szélsőséges különbségekhez vezetne, és némelyik helyi önkormányzat nem lenne képes ellátni a központi kormányzat által átadott alapfeladatokat sem. A kőzponti támogatásokra 
való támaszkodás gyengítené az autonómiát, illetve a helyi önkormányzat és a polgárok közötti közös érdekeket.

\section{Politikai lehetöségek:}

- A mobilitás gyorsitása, a városi megújulás és a társadalmi célok követése érdekében a nemzeti kormányzatnak és a helyi önkormányzatoknak egy átfogó lakảspolitikát kell követniük, és fel kell újittaniuk a szociális lakäsépitést. Az üj lakásépitések és a rugalmas felújittások során a volt normáknál lényegesen nagyobb méretü lakások támogatására kell a prioritást helyezni.

- Ösztönözni kell a lakáspiac mobilitását, e cél érdekében támogatások és segélyek széles választékát kell müködtetni.

- A hajdani állami vállalatokat fel kell szabaditani a kommunális szolgáltatások és eszközök fenntartásának súlya alól, amelyek nem egyeztethetök össze üzleti tevékenységükkel. Ezeket a létesítményeket a helyi önkormányzatoknak kell üzemeltetniük, ezáltal a városokban egy sokkal átfogóbb és jóval racionálisabb szolgáltatás-biztositási politika valósulhatna meg.

- Számos szolgáltatást szervezhetnek vagy elláthatnak magánvállalkozók is. Ezek elöfeltétele a feladatok és kötelezettségek részletes meghatározása, a tiszta és nyilvános tender, az egyenlö támogatási feltételek biztositása a felek részére szektortól és személytól függetlenül, valamint a szigorú értékelés. A finanszírozást és a szolgáltatás-ellátást szervezetileg el kell különíteni, még akkor is, ha a szolgáltatást végzö az önkormányzat saját szervezete.

- A helyi önkormányzatok bevételeinek tartalmaznia kell mind a helyi adóbevételeket, mind a központi támogatásokat. A támogatásnak normativnak és globális természetünek kell lenni, mellözve a túl részletes ágazati specializációt, engedélyezve a helyi önkormányzatnak saját prioritások felállitását. A helyi adóknak lehetôleg stabil jövedelmet kell biztositaniuk, ügyelni kell arra, hogy könnyen lehessen öket regisztrálni és beszedni, és nem szabad csak a helyi adófizetók egy csoportjára vagy típusára koncentrálni. Világos szabályozás szükségeltetik a költségvetési támogatások és segélyek helyi önkormányzatokhoz való leosztását illetöen. Azon esetekben, amikor a helyi önkormányzatok az állam ügynökeként cselekednek, a támogatásoknak a teljesitett szolgáltatások egységére vetítve egyenlönek kell lenniük minden egyes önkormányzatnál.

- Azokat a szolgáltatásokat, amelyeket nem csak egy közösség, hanem egy nagyobb térség számára biztositanak, a regionális kormányzatnak kell ellátnia, vagy - amennyiben helyi önkormányzat teljesiti e feladatokat - speciális megállapodásban kell rendelkezni a támogatásról, hogy ne jelentsen plusz terhet a nagyobb térség számára szolgáltatásokat biztositó város polgárainak.

\section{C) A vidéki térségek fejlesztése}

A keleti VISION térségekben sokkal nagyobb és jóval heterogénebb a vidéki térségek problémája, mint Nyugat-Európában. Bár a vidéki térségek többsége elvesztette kizárólagos mezőgazdasági karakterét, azonban a mezőgazdaság szerepe még 
mindig sokkal nagyobb ezekben az országokban, mint Nyugat-Európában. Európa (Oroszországot nem számítva) teljes mezőgazdasági aktív népességének 70\%-a a VISION térségben él és dolgozik, 90\%-uk annak keleti, 10\%-uk nyugati felén. A teljes mezógazdasági aktiv népesség közel 15 millió fö, míg a jelenlegi EU egészében számuk mindössze 9 millió.

A vidéki térségek struktúrájában, infrastrukturális felszereltségében és szolgáltatásokkal való ellátottságában megmutatkozó különbségek az egyes országok különbözö fejlödési szintjeinek következményei. A vidéki települések szerkezetére is hatással van a földrajzi környezet. Hegyvidéki térségekben (Alpok, Kárpátok) a szétszórt település típusok a dominánsak, míg a sík területeken a nagy vidéki települések és a központositottabb struktúrák az uralkodók. Néhány országban a vidéki térségek a mezőgazdaság elsődleges szerepével jellemezhetők, míg másutt a mezógazdasági foglalkoztatás csak másodlagos jelentőségü a vidéki telepủlések többségében. Következésképpen a VISION országok között lényeges különbségek vannak már a vidéki térségek meghatározását illetően is (mezögazdasági, vagy nem városi funkció).

Az elmúlt évtizedben olyan alapvetó változások mentek végbe a keleti VISION országok vidéki térségeiben, amelyek döntő hatással vannak a vidékpolitikára. A változások azonban az egyes országokban igen eltéróek voltak. A fejlemények négy típusa különböztethető meg:

- Az elsô típus a Cseh Köztársaságban, Szlovákiában, Magyarországon és a volt Német Demokratikus Köztársaságban figyelhetô meg. Ezekben az országokban a mezőgazdasági fơldeket visszaadták eredeti tulajdonosaiknak, vagy privatizálták, azonban figyelembe véve, hogy az elmúlt évtizedekben a lakosság nagy része elhagyta a vidéket, a mezögazdasági földek nagy része olyan volt termelöszövetkezetek használatában maradt, amelyek gazdasági társasággá alakultak át. A társaságok mentesültek azon kötelezettség alól, hogy minden tagjukat foglalkoztassák. A mezőgazdasági földek másik részét egyéni farmerek müvelik. Kisebb részük valamilyen speciális ủzleti vállalkozássá alakult át, és piacra termel. Jelentős részük azonban önellátásra törekszik, alig végez beruházásokat, és szinte semmit sem termel a piacra. E történések következtében a mezőgazdasági foglalkoztatottak száma jelentős mértékben csökkent. Kialakult egy nagy és kis gazdaságokra épülö multi-szektorális mezőgazdasági termelés, amelyben - ez idáig - a közepes méretủ vállalkozások alulreprezentáltak.

- A második tipusú fejlődés Romániában, Bulgáriában és Albániában figyelhetö meg. A mezőgazdasági földek visszaadására ezekben az országokban is sor került (Albániában részleges szétosztás), de az elözỏ csoporttal ellentétben a termelöszövetkezetek és az állami gazdaságok többsége felbomlott, és a kis méretú farmok váltak meghatározóvá. A városi munkanélküliek egy része a privatizált mezógazdaságban talált munkalehetöséget (többségük azelött a nem mezögazdasági állás mellett mellékfoglalkozásként a mezögazdaságban is dolgozott). Az előző ország-csoporttal ellentétben a mezőgazdasági foglal- 
koztattak száma tovább emelkedett. A mezőgazdasági foglalkoztatottak számának emelkedése enyhítette az átmenet éveiben a munkanélküliség problémáját, de a jövőben komoly problémákat fog okozni.

- A harmadik csoporthoz tartozik Lengyelország és Szlovénia, ahol a nagyarányú kollektivizálás nem volt nagymértékủ a múltban, ezért nem volt szuikség erős privatizálásra sem. A foglalkoztatási szint és a mezógazdasági foglalkoztatottak aránya ezekben az országokban többé-kevésbé allandó maradt. Itt a legfontosabb problémát nem a tulajdonosi kapcsolatok átalakítása jelentette, hanem az alacsonyabb agrártámogatás, és az EU-ból származó agyontámogatott agrárimport nyomása. Lengyelország egy vegyes eset. Dél- és KeletLengyelországban a helyzet inkább a romániaihoz hasonlítható, ahol a mezögazdaságban nőtt a foglalkoztatás. Észak- és Nyugat-Lengyelországban, ahol azelött nagy állami gazdaságok müködtek, inkább a többi közép-európai országra hasonlít a helyzet, ugyanis a mezőgazdasági privatizáció jelentősen csökkentette a foglalkoztatást a vidéki térségekben.

- Végül a negyedik típust a volt szovjet köztársaságok, Ukrajna és Moldova képviselik, ahol a vidéki térségekben még csak most kezdődik el az átalakulás. A föld nem lehet magántulajdon, az új egyéni farmerek esetében csak „bejegyzik a nevükre”. A mezőgazdasági és vidéki térségek a régi jogi, intézményi és szervezeti keretek között stagnálnak, és tovább hanyatlanak.

A keleti VISION országokat a termőföldeknek a földterületeken belüli nagy aránya jellemzi. A mezőgazdasági termelés természeti adottságai általában kedvezőek, de néhány országban a termőföldek jelentős része kevésbé alkalmas hatékony mezőgazdasági termelésre: a termótalaj gyenge minőségú, komoly degradáció veszélyének van kitéve, és kedvezőtlenek az egyéb földrajzi adottságok (domborzat, csapadék, hőmérséklet). A termőföldek víz és szél általi eróziója különösen a bortermelő vidékeken és az extenzív meliorációjú területeken jelentkezik.

A legtöbb VISION országban elkerülhetetlen a mezôgazdasági foglalkoztatottak számának és a müvelt területek nagyságának csökkentése. A kérdés az, hogyan kell ezt a csökkentést véghezvinni: a mezőgazdasági termelésnek a legtermékenyebb területeken való koncentrációjával és a mezógazdaság hatalmas területeken való felhagyásával, vagy fokozatosan úgy, hogy mindenhol a környezetbarát termelési módokat erősítik és támogatják. Az utóbbi alkalmazása kedvezőbb, de a keleti VISION országok többsége nincsen abban a helyzetben, hogy kizárólagosan a mezỏgazdaság pénzügyi támogatásával megvalósitsa azt. Ezért a vidéki térségek jövője csakúgy, mint a mezőgazdaság jövője, az újjáépités sikerére, és a nem mezőgazdasági szektorokban képződő jövedelmek lehetőségére számít. Azonban az országok gazdasági helyzete, a világpiaci tendenciák és az EU közös agrárpolitikája (CAP) megújításának iránya és módja mind olyan tényezők, amelyek jelentősen befolyásolják ezt a folyamatot.

A vidéki térségek többségében fel nem használt, nem mezőgazdasági ismeretek és kihasználatlan adottságok, létesítmények vannak. Ezeket összefoghatná egy, a kis- 
és középvállalkozásokat támogató és segitoó vidékpolitika. Ezek az intézkedések az átalakulás igen fontos elemeivé válhatnának.

$A$ vidéki települések nagy része kicsi. A keleti VISION térségben 97000 község található, kétharmaduk lakossága nem éri el az 1000, a közel 50\%-é pedig az 500 föt sem. Igen gyorsan nő e településeken az alap kommunális szolgáltatások biztosításának költsége. A kis települések nagy részében a lakosság szinte kizárólag idős emberekből áll, akiknek elsősorban szociális ellátásra van szükségük. Általában minél kisebb egy település, annál idősebb a lakossága. Az elöregedő vidéki népességgel való törődés lesz az elkövetkezendő évtizedek egyik legfontosabb szociális feladata.

A vidéki helyi önkormányzatok visszanyerték autonómiájukat, jogi és pénzligyi hatáskörüket megerősítették. Nagy részük azonban nincsen abban a pénzügyi helyzetben, hogy megvalósítsa a legfontosabb közmüveket és infrastrukturális fejlesztéseket, illetve, hogy helyettesítse a hajdani szövetkezetek vidékfejlesztési tevékenységét.

A vidéki környezetet veszélyezteti az infrastruktúra-fejlesztés bizonytalansága. A vízvezeték-hálózat és ellátás a vidéki térségekben dinamikusan fejlödik, a vízfogyasztás ezzel párhuzamosan növekszik. A szennyvízhálózat azonban nem tart e dinamikával lépést. Következésképpen a vidéki települések talajvize erősen szennyezetté válhat. Hasonló ellentét figyelhető meg a hulladékkezelés területén is.

A szövetkezeti gazdálkodás évtizedei alatt az egyéni mezőgazdasági tevékenység nem volt megengedett, vagy igen szük határok közé volt szorítva. Ezért a vidéki házépítések csak lakófunkciókat szolgáltak, és csak e cél érdekében tervezték, építették a házakat. Most a privatizációt követően, ezek a házak és telkek nem megfelelőek már a közepes mezőgazdasági tevékenység gyakorlására sem, ami a magángazdaságok fejlesztésének komoly gátja.

A privatizáció miatt részben enyhült a nagyméretü egységes gazdálkodás és monokultúra nyomása a környezetre. Másrészt a kisméretü magángazdaságok új környezeti veszélyek forrásaivá váltak. A nagyméretủ öntözỏ és vízelvezetỏ hálózatok fenntartása egyre nehezebb. A privatizált erdőkben fennáll az erdőirtás, a visszaadott védett vidékeken pedig a nem megfelelö müvelés veszélye. Másrészről a nem megfelelö erdőtelepítés is komoly környezeti következményekkel járhat (biodiverzitás elvesztése, talajvízszint csökkenése stb.).

\section{Politikai lehetôségek:}

- A keleti VISION országokban a területfejlesztési politika legfontosabb célkitũzése kell, hogy legyen a vidéki átalakulás. Ez azonban nem jelentheti azt, hogy csak a nem mezógazdasági tevékenységeket kell támogatni. A mezőgazdasági foglalkoztatottak nagy számát (egyes országokban), és a mezögazdasági termelés visszaesése okozta jövedelemcsökkenést figyelembe véve a vidékfejlesztési probléma nem oldható meg a mezõgazdaság jövedelemtermelõ képességének és hatékonyságának erôsitése nélkül. A vidékfejlesztési politika nem azo- 
nos az agrárpolitikóval, de a versenyképes és környezetbarát mezőgazdaság támogatảsa annak fontos és nélkülözhetetlen része.

- A vidéki térségek gazdasági bázisának diverzifikációjára szintén szükség van. E célból a mezógazdasági termelés folyamatát és a kis- és közép méretũ ipari és szolgáltató vállalkozásokat kell támogatni. A turizmus is fontos kiegészitõ tevékenység, különösképpen azért, mert egyben a vidéki gazdaság-értékesitési lehetőségeit is jelentheti. Az erdészet szintén egy fontos többcélú tevékenység.

- A vidéki átalakulás egy fontos elófeltétele a vidéki szakképzési oktatási rendszer megújítása, amelyre ma még jellemzõ az agrárdominancia. A szakképzésnek csakúgy, mint az oktatásnak, különösen a vidéki térségekben ki kell használni az információs társadalom elönyeit. A telekommunikáció rengeteg lehetőséget kinál a ritkán lakott és földrajzilag periférikus térségek számára. A vidékpolitikának sikerre kell vinni e lehetóségeket.

- A vidék újjáépitését azonban nem lehet megvalósitani csupán az egyes települések keretében. A falvaknak a fejlesztésekhez szövetséget kell létrehozniuk a többi településsel, mindenekelött a vonzáskörzetek központjait alkotó városokkal. A központi és a regionális kormányzatnak segiteni kell ezeket az együttmüködéseket, elsősorban a több településre kiterjedö társulások és közös projektek támogatásával.

- A vidéki helyi önkormányzatoknak minden eddiginél nagyobb szerepet kell játszaniuk a strukturális átalakulásban.

- Megoldást kell találni a kis, szétszórt településeken élő idős emberek szociális ellátására.

- A vidéki térségekben az infrastruktüra-fejlesztés legfontosabb célkitũzései a következókre irányulnak: az elérhetőség javitása, a viz- és a szennyvizhálozzat, illetve az energiahálózat és a hulladékfeldolgozási hálózat fejlettségi szintje közötti különbség csökkentése.

- Új tervezési és épitési szabályozásokat kell alkalmazni a vidéki térségekben, a települési terveket, ha szükséges felül kell vizsgálni, hogy az üj körülményeknek megfelelhessenek.

- Új törvényi szabályozásra van szükség a földhasználat és a természetvédelem területén, amely igazodik a privatizált és kistermelöi mezógazdaság új feltételeihez.

\section{D) A közlekedés és a telekommunikảció fejlesztése}

\section{D.1) Közlekedés}

A VISION országok mindegyikének közös jellemzöje, hogy egyre nagyobb erőfeszítéseket tesznek a nemzetközi közlekedési és telekommunikációs hálózatok fejlesztése érdekében. A közlekedés-fejlesztésben a prioritást mindenhol a multimodális közlekedési folyosók kiépítésére, a nemzeti közlekedési hálózatoknak a szomszédos országokéval való jobb összekapcsolódására, és a környezeti normákkal való jobb egyeztetésre helyezik. A közlekedés-fejlesztést azonban nagymérték- 
ben befolyásolják a VISION térség keleti és nyugati felén lezajló különböző strukturális átalakulások.

Az elmúlt évtizedben négy fö változás határozta meg a közlekedés szerepét és szerkezetét:

- A vasúti szállításról a közúti szállításra való áttérés;

- A tömegközlekedésről az egyéni közlekedésre való áttérés;

- A belföldi szállításról a nemzetközi szállításra való áttérés;

- A közlekedésnek a keleti határról a nyugati határra történő áthelyeződése.

A keleti VISION országokban a kilencvenes évek elejéig a vasúti szállítás és közlekedés játszott domináns szerepet, aránya sokkal magasabb volt, mint az EU országokban. Az 1990-es évek óta azonban a keleti országokban drámaian csökkent a vasúti szállitás volumene, 1994-ben az 1990-es szintnek már csak 50\%-át érte el, míg a közúti szállítás részesedése folyamatosan emelkedett. Míg a nyugati kormányok hatalmas erőfeszítéseket tesznek azért, hogy a szállítást a közútról a vasútra tereljék, addig a keleti országokban egy éppen ezzel ellentétes, piac vezérelt, drámai változás folyik.

Ugyanez az ellentmondás tükrözödik a közlekedési hálózatok fejlesztésének projektjeiben. Míg a TEN hálózat projektjei az EU tagállamokban elsödlegesen a nagysebességü vasúthálózatok modernizációjára és fejlesztésére fókuszálnak - e célkitüzésre szánják a források $80 \%$-át -, a keleti VISION országokban a források 52\%-át autópálya-épitésekre szentelik (TINA hálózat), a vasút aránya pedig csak $36 \%$. Még akkor is, ha számitásba vesszük az autópályák alulfejlettségének állapotát, ezen ellentétes irányok új egyenlőtlenségek növekedését okozhatják. A TEN és a TINA program befejeztével a keleti országoknak vasúthálózatuk inkompatibilitásával kell majd szembenézniük.

A tömegközlekedésröl az egyéni közlekedésre való áttérés szoros kapcsolatban áll a vasútról közútra való áttéréssel. Az okok hasonlóak: a kormányok már nem képesek finanszírozni a tömegközlekedés támogatását oly módon és hasonló összegekkel, mint azelött. Ez alatt a keleti VISION országokban dinamikusan növekszik a magán személygépkocsik száma. A tömegközlekedesröl a magánközlekedésre való áttérés a környezeti és az energiahatékonysági következményeken kívül társadalmi következményekkel is jár: A tömegközlekedés visszaesése az emberek - különösen az idősebbek - számára a mobilitástól való megfosztottságot jelenti. A tömegkőzlekedés visszaesésének különösen két területen van komoly következménye: a városok (részben vidéki) vonzáskörzeteiben és a nagyvárosi agglomerációkban.

A belföldi szállitásról a nemzetközi szállitásra történö áttérés szoros kapcsolatban áll a gazdaság strukturális változásával. Az import és export aránya - a közbülsỏ és a végső fogyasztásban egyaránt - növekedett. A személyszállitás területén a belföldi ingázás csökkent, a nemzetközi forgalom azonban növekedett. A határátkelőhelyek szük keresztmetszetté váltak, és sürgös feladattá vált a transznacionális úthálózatok kapacitásának növelése. Ez tükröződik Közép- és Kelet-Európában a transzeurópai közlekedési folyosók kijelölésében is. A fejlesztések azonban felgyorsítják a már meglévő változást, és a közlekedésfejlesztési projektek néhány fontosabb 
transznacionális útvonal vagy csomópont - föként a fövárosok - köré való koncentrálódását. A beruházások koncentrációja ezen európai korridorok mentén felerősíthetik a közlekedési hálózatok meglévó hierarchikus, centralizált struktúráját.

A nemzetközi szállításban egy másik igen fontos változás is történt. Mind az áru-, mind a személyszállításban jelentős mértékben emelkedett a nyugat-európai piacgazdaságokból, illetve az azokba történó szállitás, míg a közép-és kelet-európai országokkal való közlekedési kapcsolatok intenzitása csökkent. A keleti - volt szovjet - határokon meglévö átrakodó kapacitások, széles nyomtávú vasútvonalak kihasználatlanokká váltak, viszont a nyugati határokon és az arra vezető szállitási útvonalakon komoly szük keresztmetszetek alakultak ki. Az elmúlt években a szomszédos keleti VISION országok közötti kereskedelem újra növekedésnek indult kiegyensúlyozottabb gazdasági és közlekedési kapcsolatokat eredményezve.

Az 1989-1990-es politikai és gazdasági változásokat követően az infrastruktúrafejlesztés ismét elsődleges célkitűzéssé vált, és több országban elsősorban az autópálya-építésekre helyezték a hangsúlyt. Más országokban azonban visszaesett a közlekedési beruházásoknak az aránya (különösen a délkelet-európai országokban), a jelenlegi ütemben az ambiciózus közlekedéshálózat fejlesztési tervek nehezen hajthatók végre.

Az elmúlt évtizedben csökkent a belföldi vizzi szállitás, főleg a gazdasági és szerkezeti váltás, illetve részben a politikai fejlemények miatt, és csak a legutóbbi években indult újra növekedésnek. A vízi szállitásnál a legföbb visszatartó erő a multimodális szállítási központok hiánya és az elégtelen gazdasági ösztönzés és támogatás.

A légi közeledés és szállitás ezzel ellentétben dinamikusan növekszik, és a multimodális szállítási kapcsolatok erősítésében fontos szerepet játszik. A magánrepülőgépek számának növekedésével a regionális repülőterek újra visszanyerhetik gazdaságos müködtetésük igazolását. A viszonylag kis közép- és délkelet-európai légitársaságok stratégiai partnerkapcsolatokat vagy szövetségeket fognak kialakítani a nyugati társaságokkal és/vagy egymással, hogy versenyképessé válhassanak a globális versengésben.

A VISION térség két felének villamos energia rendszere, illetve az olaj és gázvezetékek hálózata a múltban egymástól elkülönült. Az egyik legfőbb feladat most, hogy ezeket az energiaforrások diverzifikációjának és az ellátás biztositásának érdekében összekapcsoljuk. A meglévő csővezetékek már sok esetben régiek, és az új energiaforrások felfedezése is korszerübb vezetékek megépitését teszik szükségessé. Az egész világra kiterjedỏ verseny folyik ezen új energiaforrásokhoz való csatlakozásért. E téren nagymértékben javíthatja a VISION országok pozícióját a közös stratégia.

\section{Politikai lehetôségek:}

- Minden VISION országban a gazdaság- és szociálpolitika legfontosabb feladatai közé kell sorolni a közlekedési és telekommunikációs infrastruktúra fejlesztését. Az elérhetőség javitása a területi politika összes alapcélkitüzését szolgálja. 
- A területfejlesztési politikának biztositania kell, hogy a nemzetközi hálózati tervezés ne kerüljön ellentmondásba az egyes országok hosszú tóvú területfejlesztési koncepcióival. Egyértelmũen szükséges a területfejlesztés általános megközelitésének és e dokumentumban lefektetett prioritásainak koordinálása a közlekedés-fejlesztési programokkal.

- A legfontosabb feladat a VISION térség keleti és nyugati fele közötti közlekedési kapcsolatok kiépitése. El kell kerülni az egyoldalú közlekedés-fejlesztést. A területfejlesztési politikának biztositania kell, hogy a VISION térség keleti felében a már meglévö közlekedési infrastruktúrákat ne hanyagolják el azon térségekben, ahol a jövóben várhatóan megújuló gazdasági kapcsolatok a közlekedés növekedéséhez vezetnek. Továbbá figyelmet kell forditani a közlekedési folyosók azon délkelet-és a kelet-európai részeire (különösen az 5-ös, 8-as, és 10-es folyosó), amelyeket még nem tartalmaznak sem a TEN, sem a TINA programok.

- A TEN és TINA programok allokációja során az országok mindkét csoportjában még nagyobb koordinációra és konvergenciára van szükség. Számos esetben a javasolt föbb útvonalaknak a határ másik oldalán nincs folytatása. Még fontosabb a prioritások koordinálása és az ütemezés. Több figyelmet kell fordítani a közepes és nagy tóvolságú szárazföldi közlekedésben a vasúti infrastruktúrára.

- A keleti VISION városok egyik ritka elõnye a hatékony és súrũ tömegközlekedési hálózatuk. Megéri öket megörizni és továbbfejleszteni. A vasúthálózat modernizációjának (gyorsvasủt, kétvágányuisitás stb.) prioritást kell kapnia.

- Néhány kelet-európai VISION ország esetében újra át kell gondolni az autópálya-épitési projekteket, mert komoly eladósodáshoz és/vagy más fontos célkitüzések (pl. tömegközlekedés) elhanyagolásához vezethetnek. A nemzeti prioritásokkal és programokkal összhangban lévoo új utak, autópályák épitésére való vállalkozás elôtt általános feladat a már meglévố és elhanyagolt úthálózat, illetve annak korszerüsitésében rejlö lehetőségek kihasználásának átgondolása. Szükséges azonban néhány fö közlekedési folyosó autópályává fejlesztése. E projektekhez nélkülözhetetlen a nemzetközi támogatás.

- A multimodális és a rugalmas szállítás különösen fontos ezekben az országokban. Létre kell hozni a multimodális szállitást szolgáló logisztikai központok hálózatát. A hálózatnak fontos csomópontjai a határátkelöhelyek és a kikötök (tengeri és folyami). Az új közlekedési hálózati elemek tervezése során integrált megközelitést kell alkalmazni, figyelembe véve azok gazdasági, társadalmi és környezeti hatásait és kölcsönös függőségét. A multimodális szállitást gazdasági eszközökkel is támogatni kell. A multimodális kapcsolatokra különösképpen szükség van a repülötereknél, továbbá az Adriai-tenger két partja között, és a délkelet-európai térségben az Adriai-és a Fekete-tenger között.

- Az egységes és liberalizált európai közlekedés elöfeltételeként nagyon fontos a közlekedési hálózatok technikai, biztonsági és jelzörendszereinek standardizálása. 
- A közlekedési együttmüködés egyik lényeges szempontja, hogy a szárazfóldi országok számára a többi, kikötövel rendelkezö ország megbizható és kedvezö elérhetöséget kináljon. A Dunának, mint a tenger elérésének legkényelmesebb útjának, igen fontos szerepet kell játszania e téren.

\section{D.2) Telekommunikáció}

A VISION térségben a telekommunikáció jelenleg a legdinamikusabb szektor. A telekommunikációs infrastruktúra a közép- és kelet-európai országokban általában még nem igazán fejlett, inkább régi technológiákon alapul. A régi telekommunikációs infrastruktúrák modernizációja és fejlesztése nagy piaci lehetőségeket kínál, és vonzóak a külföldi befektetök számára. A privatizáció ebben a szektorban a fejlódés húzóereje. A keleti VISION országokban az elkövetkezendö években a telekommunikáció fö technológiai trendjei befolyással lesznek a területfejlesztésre: a telefonhálózatok digitalizálása, a nemzetközi hálózatok felé történó kapcsolatok számának és minöségének javitása, értéknövelö szolgáltatások nyújtása, a mobil kommunikáció dinamikus fejlődésének kihasználása.

Mint az EU legtöbb országában, a VISION térségben is alacsony még a telekommunikáció súrüsége a városi központokon kívül. Nagyon fontos, hogy a kormányzatok megcélozzák az infrastrukturális fejlesztéseknek és az információs társadalomba való átmenetnek a területi szemléletét. A gazdasági és társadalmi fejlődéshez szükséges, hogy a modern telekommunikációs infrastruktúrák és szolgáltatások a tér minden pontján elérhetők legyenek. A müszaki és gazdaságossági megtérullés szemléletek fontos területei azon beavatkozásoknak, amelyek célja a gazdasági és társadalmi hátrányok felhalmozódása kockázatainak csökkentése a ritkán lakott, vagy általában a telekommunikációs szolgáltatások iránt kisebb kereslettel rendelkezö területeken.

A VISION térségben néhány ország a határ menti térségekben már bevezetett valamilyen speciális dijjszabási engedmény-rendszert a kulföldi szomszédos régiókba irányuló telefonhívások esetében. Ezek a külföldi tarifák még nem általánosak a keleti VISION országok között. Az engedményes külföldi tarifák hiánya a határ menti térségekben gátja a gazdasági fejlődésnek, és indokolatlanul akadályozza a határon átnyúló kapcsolatokat.

\section{Politikai lehetöségek:}

- A közép- és délkelet-európai országoknak megvan a késón indulók elönye, miszerint a legújabb technológiákat alkalmazhatják telekommunikációs rendszerük kiépitése során. Ezeket a legújabb eredményeket, mint komparatív elönyöket ki kell használni a VISION országok jövőbeli területfejlesztésében, mint például a vidékfejlesztésben vagy a vonzó szolgáltatási iparágakban. Az e területeken megkezdett fejlesztéseket továbbra is támogatni kell. A területfejlesztési politikának hozzá kell járulnia e célhoz, azzal hogy növeli a tudatosságot, és támogatja a területi szereplöket e lehetôségek kihasználásában. 
- A VISION országokban az alapvetö telekommunikációs szolgáltatások, illetve az információs infrastruktúrák és alkalmazások szempontjából szükség van a regionális egyenlötlenségeket bemutató területileg differenciált információra.

- Néhány ország és üzemeltetö között olyan intézkedések meghozatalára van szükség, amelyekkel a nemzetközi telekommunikációs díjakat összhangba hozzák, hogy ezáltal megszüntessék a határ menti térségekben a viszonylag kis távolsáyú nemzetközi hivások rendkívül magas árait.

E) Környezetvédelem, a természeti és kulturális örökség kezelése

\section{E.1) A környezetvédelem feladatai}

A környezeti minőség a nemzeti és regionális fejlesztés alapvető szempontja. A természetes környezeti struktúrák degrádálása fenyegeti az erdészetet és a halászatot, az ivóvízellátást, a rekreációt, sőt még a mezőgazdasági tevékenységeket is. A levegö, a víz és a talaj szennyezése az élő környezet minőségét fenyegeti. A hatékony környezeti politikák alapvető célja a hosszú távú fenntartható fejlődés.

A keleti VISION országokban az elmúlt évtizedben néhány alapvetö változás ment végbe a környezet állapotában, amelyek meghatározzák a jövőbeli feladatokat és a környezet-politikai stratégiát.

A keleti VISION országokban az 1990-es években a leginkább szennyezö anyagok emissziója jelentös mértékben csökkent. Ez a pozitív változás csak részben köszönhető a kormányzatok hatékonyabb környezeti politikájának. A csökkenő szennyezöanyag kibocsátás másik oka a hanyatló ipari és mezőgazdasági termelés volt. A környezetet leginkább szennyező iparágakban (vaskohászat, vegyipar, építỏanyagipar) a hanyatlás sokkal gyorsabb volt, mint a többi ágazatban. A mezőgazdaságban az előző szint töredékére esett vissza a vegyszerek (mütrágyák, gyomirtók stb.) használata. Felszámolták a talajt és a talajvizeket legjobban szennyezö nagy állattenyésztö telepek egy részét. Az eredményekhez kétségtelenül hozzájárultak a kormányzati intézkedések is, például a szennyezés legveszélyesebb forrásainak bezárása. Ugyancsak fontos szerepet játszott az Európai Unió segitsége és nyomása is.

A múltban a szennyezés kibocsátásának legnagyobb részéért néhány nagy ipari üzem volt a felelős. A környezetszennyezés ellenőrzése és szankcionálása - elméletileg - nem volt nehéz feladat, azonban jelentős politikai akadályai voltak. Jelenleg, bár még a nagy ipari térségek a szennyezés legfontosabb forrásai, rengeteg kisvállalkozás müködik, amelyek közül sok szennyezi valamilyen mértékben a környezetet. A régi környezeti igazgatás képtelen a szennyezés e sokrétú forrásának kezelésére. A szabályozások végrehajtásának korlátjai ma nem politikai, inkább adminisztratív jellegủek: nevezetesen, hogy képtelenség ellenőrizni a szennyezőket. A „polluter pays" (a szennyező fizet) elve alkalmazható lenne az új helyzetre, ugyanakkor a bírságok és büntetések behajtása szinte lehetetlen feladat mind adminisztratív, mind gazdasági nézöpontból. 
A jelenlegi szennyezés csökkentése mellett ott van a múlt öröksége, a felhalmozott környezeti károkkal való megbirkózás, ami magába foglalja a külszíni fejtésú bányák, az ipari telephelyek és a szemétlerakó helyek rekultiválását. Néhány országban (volt NDK, Cseh Köztársaság, Magyarország, Lengyelország, Szlovákia) az elhagyott volt szovjet laktanyák és katonai bázisok súlyosan szennyezettek. A helyreállítás vagy rekultiváció költsége igen tekintélyes összegre rủg, amelyeket a keleti VISION országok nem képesek egyedül viselni.

A szennyezés és a természeti erőforrások kezelésének komoly problémájával rendelkező nagy térségek gyakran határrégiók, amelyek transznacionális együttmüködést igényelnek. A természeti környezet minőségének fenntartásában és a transznacionális politika kialakitásában nélkülözhetetlen a határokon átnyúló együttmúködés. A nyugati széllel kelet felé terjedő szennyező kibocsátás, a folyók mentén feljebb fekvő országokban beszennyezett vizek lefolyása az alacsonyabban fekvő országokba és a tengerparti területekre kölcsönösen összefügg. Az alapvetö földrajzi tények az országok környezeti helyzetét nagymértékben kapcsolatba hozzák a transznacionális szinttel.

Az európai környezeti politikák növekvő hatása a nemzeti környezeti politikák kialakítására élénkiti és modernizálja a nem tagállam országok eddigi erőfeszítéseit. A nemzeti jogi szabályozásban az EU környezeti joganyagának adaptációs folyamatában növekedni fog a környezetvédelem fontossága.

Néha riasztó pénzösszegekre hivatkoznak az EU környezetvédelmi standardok kőzösségi joganyagának átvételével kapcsolatban. A szükséges beruházások tényleg nagyok, azonban azok nagy részét magánszereplők fogják kivitelezni a szerkezeti átalakulás folyamán: a régi személygépkocsikat újakra cserélik, a régi elértéktelenedett eszközök helyett újakat helyeznek uizembe stb. Az elmúlt tíz évben már megmutatkozott a szerkezetváltás hatása a környezet javításában. Hátra van még egy nagyobb és sokkal nehezebb feladat is: a társadalom környezet iránti szemléletének megváltoztatása. A szennyezés nagyrészt nem az elavult technológiák következménye, hanem az emberi érdektelenségnek, a környezetvédelmi szabályozások megszegésének és környezetünk tisztảntartására fordított nem elegendő eröfeszitésnek.

\section{Politikai lehetőségek:}

- A nemzeti programoknak a legnyomasztóbb környezeti problémák megoldására kell fókuszálniuk. Az új helyzet úffajta szabályozást, igazgatást és végrehajtási folyamatot igényel. A legtöbb országban a szabályozást még nem igazitották teljes mértékben ehhez az új helyzethez.

- Szükséges különösen a közlekedési forgalomra vonatkozóan az energiaárak és a környezetvédelmi standardok emelése.

- A nagyobb fejlesztési projekteknél kötelezövé kell tenni környezeti hatástanulmány készitését, mert ezek tartalmazzák azokat a tisztán környezetgazdálkodási üzeneteket, amelyekkel kapcsolatban az államigazgatásnak, valamint a helyi és regionális önkormányzatoknak kell eljárni. 
- A fenntartható fejlődés gondolatán alapuló nemzeti környezeti terveket kell kidolgozni, s ezekben kell meghatározni a kvantitativ kötelezó, illetve nem kötelezö védelmi célokat is.

- A nemzeti és a regionális kormányok politikája gazdaságilag ösztönözheti a környezeti szempontból megfelelö tevékenységeket. E célból szintén szükség van a változásra, a környezetvédelemnek egy sokkal decentralizáltabb menedzsmentje és igazgatása kivánatos. A nem kormányzati szereplök szerepét erösiteni kell csakúgy, mint a helyi és regionális önkormányzatok kezdeményezéseit.

- Gyakorlatilag azonban a legnagyobb kihivás a nemzeti, regionális és helyi közigazgatás és önkormányzat kapacitását éri a kivánatos EU környezeti politikák és standardok végrehajtása során. A közigazgatási struktúra modernizációjára van szükség, hogy a helyi és regionális környezeti igazgatás és az önkormányzatok képesek legyenek fogadni az EU és más nemzetközi támogatásokat.

- Nagyon fontos a degradált területek környezeti rehabilitációja.

- Különösen szükséges a transznacionális együttmüködés az olyan nagymérvủ közös eröforrások és környezeti-természeti és kulturális vagyonok esetében, mint az Adriai-és a Fekete-tenger, az Alpok és a Kárpátok.

- Néhány esetben a privatizációt össze lehetne kötni a környezeti rehabilitációval oly módon, hogy a szerzödések - megfelelö privatizációs árengedmények beépitésével - magukba foglalják a szennyezés csökkentésének kötelezettségét is.

- Rengeteg oktatási eröfeszitésre és helyi kezdeményezésre lesz szükség az emberek saját környezetükre irányuló attitüdjeinek megváltoztatásához.

\section{E.2) A természeti örökség kezelése}

A természeti örökség minden országban fontos részét képezi a környezeti állapotnak és az éló környezetnek. A biodiverzitás és a természeti örökség általában az ipar, az intenzív mezógazdaság, a közlekedés és urbanizáció, illetve a turizmus egymással ellentétes hatásainak van kitéve. A hatékony megőrző politikák a biodiverzitás fenntartását, és a természeti örökség védelmét célozzák meg, amelyek hangsúlyos pontként szerepelnek minden hosszú távú fenntartható fejlödési jövöképben.

A VISION térségben óriási a biodiverzitás. Az Alpok és az Alpokalja vegetációs közösségei, az eredeti erdők, vizes területek, tözegmocsarak és tavak, a Duna és a többi kisebb folyó partját takaró erdők, a homokdủnék, az Adriai- és a Feketetenger partvidékét övezö egyedi természetes környezetek Európa e részén a természeti örökség igen gazdag képét alakítják ki. Azonban minden országban komoly problémát jelent a természeti környezet megörzése, és az egyedi természeti környezetek és tájképek degradálódásának veszélye fenyeget.

A természeti örökség legértékesebb részeinek megörzéséhez az intézményi feltételek már biztosítottak. A keleti VISION térségben egy kiterjedt nemzeti park hálózatot hoztak létre. A nemzeti parkok területének aránya az egyes országok területéhez viszonyitva lényegesen magasabb e térségben, mint Európa nyugati felében. Az 
Európában nemzeti parkként deklarált összes terület több mint fele a VISION térségben található. Azonban a nemzeti parkok irányítása és fenntartása sok kívánnivalót hagy maga után.

Kevésbé kiterjedt a védett kulturális tájak hálózata. Jóval komplexebb szabályozásra és ellenôrzésre van szükség a sürübben lakott és az intenzivebb emberi tevékenységgel rendelkezõ térségek esetében. A nyugati országokban a védett kulturális tájak adják a védett területek nagy részét. A keleti országokban azonban arányuk jóval kisebb, néhány országban alig létezik (Moldova, Románia, Bulgária).

Különös figyelmet kell helyezni azon térségekre, ahol a nagy értékủ természeti ökoszisztémákat, környezetileg érzékeny térségeket vagy kulturális tájakat természeti csapások veszélyeztetik (pl. árvíz, aszály, erózió, tủz, fơldrengés és földcsuszamlás). Meg kell határozni, és regisztrálni kell az ilyen veszélyeknek kitett térségeket, és megfelelö mủvelési, építési, védelmi és vészhelyzetre vonatkozó szabályozást kell kidolgozni.

A kárpótlás (privatizáció) a természeti örökség védelmének ủj kihívása. Számos olyan területet kapott vissza az eredeti tulajdonos, vagy annak leszármazottai, amelyeket az elmúlt évtizedekben védett tájjá vagy a védett területek más formájává nyilvánítottak. A legtöbb kormány nem rendelkezik a szükséges jogi és financiális eszközökkel, amelyekkel a természetvédelmi célkitüzéseket figyelembevevő müvelésre motiválhatná vagy kényszeríthetné az ủj tulajdonosokat.

A legértékesebb ökoszisztémák nagy része a határ menti térségekben helyezkedik el. A határok tradicionálisan folyók mentén, hegygerinceken futnak, ezek a területek e biotópok evolúciójához a legmegfelelőbb helyet nyújtják. Ráadásul a határterületek - különösen a keleti országok nyugati határai - évtizedeken keresztül tiltottak voltak a turizmus, utazás és a gazdasági tevékenységek számára. Ez idő alatt az ökoszisztéma zavartalanul és érintetlenül fejlödhetett.

A hatalmas károkat okozó és emberi áldozatokat is követeló nagy árvizek - mint 1997 nyarán az Odera térségében - rámutatnak arra, hogy az árvíz-megelözési intézkedések transznacionális feladatok. A teljes vízgyűjtỏ terület hosszú távú térségmenedzsmentje szükséges a hasonló katasztrófák elkerülése érdekében. Hasonlóan fontos és transznacionális természetủ feladat a szárazság csökkentése/megelözése.

\section{Politikai lehetőségek:}

- A VISION térségben a nemzeti parkok hálózata jól kiépittettnek tủnik. Következésképpen a keleti VISION országoknak a jövóben a szabályozások érvényesitésére, illetve a védett területek engedékenyebb típusaira, mindenekelött a védett kulturális tájakra kell helyezni a hangsúlyt.

- Meg kell fontolni a privatizált földek egy részének a helyi, regionális és központi kormányzatok vagy nem kormányzati szervezetek általi visszavásárlásának lehetốségét, hogy elổ lehessen segiteni a védelmezési szabályozások kikényszeritését. A költségvetési alapokból egy bizonyos összeget e célra kell forditani. 
- Számos határ menti térségben ajánlott határokon átmyúló természetvédelmi területek létesitése.

- A transznacionális árviz-megelözési programoknak meg kell jelölniük az egyes folyók vízgyüjtốterületein az árvízáltal leginkább veszélyeztetett térségeket. A meglévõ árvizkockázatot speciális területi tervezéssel és a mezõgazdaság, erdőgazdaság, várostervezés, rekreáció és vizellátás földhasználatra vonatkozó intézkedésekkel csökkenteni kell. Megfelelö és széleskörũ transznacionális terveket kell kidolgozni az egész vizgyujijtôterületre a szükséges eszközök és a megcélzott intézkedések végrehajtása során felmerülō költségek meghatározásával.

\section{E.3) A kulturális örökség kezelése}

A kulturális örökség egy olyan fogalom, amely az építészeti örökségen túl tekint, és amelyben nem dominálhat kizárólagosan a múlt. A kulturális örơkség a regionális, nemzeti és európai identitás sarokköve. Ezzel összhangban e kérdést a területi tervezésnek összetett módon kell megközelítenie.

A VISION térség egész területén nagy kultúrák voltak jelen, ezt tanúsítja a közös épitészeti, régészeti, emlékmuluvi és történelmi örökség. A római, velencei, bizánciortodox, ottomán kultúrák, de a nyugati keresztény és a zsidó müvészet korszakai is kisebb-nagyobb mértékben jelen vannak minden közép- és délkelet-európai országban. A CADSES térségben a történelem folyamán végbement hatalmas változások eredményeként számos művészeti iskola vagy egyén dolgozott egy országnál több helyen. A kultúrák irányait fontos munkák jelzik, és a kulturális örökségre, illetve annak területfejlesztési hasznosítására a közös aktivitás megvalósításának területén rengeteg transznacionális egyưttmüködési lehetőséget kínál: például turizmus, vonzó belső beruházások.

Az elmúlt évtizedben annak ellenére, hogy ritka volt a mủemlékek és templomok szándékos lerombolása (kivéve Albániát és a Szovjetuniớ, illetve később a háborúk és konfliktusok idején a Balkảnt), a nem megfelelö használat és a gondatlan kezelés hatalmas károkat okozott a történelmi és kulturális örökségben. A várostervezés és a tervezési technológiák, a kizárólag hatalmas lakótelepekben, nagy terekben és széles sugárutakban való gondolkodás elpusztította a kulturális örökség számos darabját.

A keleti VISION térségben számos területen egynél tơbb nemzetiség él különböző kulturális örökséggel, és vannak olyan területek is, amelyeken olyan nemzeti és vallási csoportok éltek a múltban, melyek már nem élnek ott. E nemzetiségek kulturális örökségének megőrzése a jelenlegi lakosok feladata.

A VISION térségben a nemzetek többsége történelmük nagy része során vidéki és agrártársadalom volt. Következésképpen a vidéki és falusi kulturális örökség legalább olyan fontos számukra, mint a városi.

A kulturális ơrơkség védelme és erösítése a turizmus fontos erőforrásává fog válni. Mindez tisztán látható a mủvészeti városok és az építészeti, történelmi és mư- 
emléki érdekességek központjainak felkeresését magába foglaló idegenforgalmi csomagok iránti növekvő érdeklödésböl.

A kulturális örökség meghatározása, védelme és erösítése nem mindig követi a közös, egybehangzó és szigorú tudományos, müszaki és igazgatási irányelveket. Ezek a különbségek mindenekelött a müemlékek azonosításának és katalogizálásának módszertanában fedezhetők fel, amelyek a történelmi, építészeti, régészeti és monumentális örökség részét képezik. Különbözők az e munkáért felelős kormányzati intézmények (nemzeti vagy regionális szintü) profilja és hatásköre. Más és más a monitoring módszer, illetve a védelemre vonatkozó törvényben meghatározott kötelezettségek betartása és annak számonkérése.

A kulturális és mủvészeti értékek egy része jelenleg ki van téve annak a veszélynek, hogy esetleg kár éri a piacgazdaságba történö átalakulási folyamat nem megfelelő szabályozása miatt (müvészeti tárgyak megsemmisülése vagy csempészete).

A legnehezebben megoldandó probléma általában a megfelelö alapok hozzáférhetósége. Az érdekek és programok egyértelmü meghatározásának kell alkotnia azokat az általános alapokat, amelyeknek biztos gazdasági megtérülést kell produkálniuk.

A CADSES országokban rengeteg olyan múemlék vagy térség található, amelyet az UNESCO világörökségként ismert el. A világörökségként való deklarálás igen fontos a gyakorlati hatások (védelem és felújitás), illetve a promóció és az image közvetítés hatékonysága miatt.

\section{Politikai lehetöségek:}

- A történelmi, épitészeti, régészeti és müemlék örökség védelme nem csak kulturális érdekeken, hanem fontos politikai és gazdasági tényezökön is alapul. Ez a védelem megfelelö törvényi eszközöket igényel, sikerességét pedig a területi tervezés különböző szintjein figyelembe kell venni.

- A hatékony védelmezési és megerósitési program mindenekelött a történelmi, régészeti, müemléki örökség egységeinek meghatározását és elismerését célzó alapos kutatást és adminisztratív kritériumokat igényel. A helyreállitási munka müszaki és tudományos megbizhatósága, valamint a megóvás és javitás adminisztrativ rendszere alkotja a szükséges kívánalmakat minden beavatkozás helyességének biztositásához. A jogi szabályozásnak az egyes mũemlékek védelmétôl fokozatosan kell haladnia azok kulturális együttesei és tájképei felé.

- A jogi és szakmai megállapodásoknak a térség minden országában szükséges védelmeznie a speciális kulturális örökséget létrehozó nemzeteket és nemzetiségeket, etnikai és vallási csoportokat és azok emlékét.

- A „kulturális vonulatokat” megcélzó koordinált transznacionális beavatkozások egyszerre erősíthetik a különbözó közösségek sajátosságait, és kihangsúlyozhatják a közös értékek jelenlétét (pl. bizánci, zsidó, török vagy német kulturális irány). 
- A falusi épitészet, a folklórmüvészet és a mindennapi használatra készitett müvészeti tárgyak a közösségek gazdasági alapjának egy része mellett a helyi és regionális identitás épitésének eszközéul is szolgálhatnak.

- A nemzeti és kulturális értékek jogi védelme fontos és szükséges intézkedés, de nem terjedhet ki az összes értékre. Az oktatásnak, a helytálló információk hatékonyabb terjedésének hozzá kell járulnia a természeti és kulturális értékekre vonatkozó társadalmi attitüdök megváltoztatásához.

- A ráforditás gazdasági megtérülése az újrafelhasználás szempontjából a turisztikai eröforrások fejlesztésével együtt azok a körülmények, amelyek igazolják a közösségi hozzájárulást és a magánberuházásokat. A privatizációs szerzödésekben pontosan meg kell határozni a hasznositás feltételeit, és az illetékes hatóságoknak azok szisztematikus ellenơrzésén és felügyeletén kell fáradozniuk.

- Az UNESCO deklarációk kivételességének ellenére az új deklarációk meghozatalához elözetes megegyezésekre van szükség, azonban mindenekelött a jelenlegi védelmi irányelvek elismerése az elsödleges.

\section{A területfejlesztési jövőképek megvalósitása}

\section{1) A területfejlesztés intézményi kerete}

A területfejlesztési politikában és tervezésben kulcsszerepet játszik az intézményés eszközrendszer kialakitása. Ez nem csak azért lényeges, hogy a célok és célkitüzések végül milyen mértékben teljesíthetök (végrehajtási képesség), hanem a kezdetektöl fogva meghatározza a tervezési folyamat fogalmi összefüggését. A célok felállítása, a célkitüzések meghatározása és a stratégiák kidolgozása nagymértékben függ az intézményi háttértől. Már a tér felfogását (térség/terület, fizikai/társadalmi struktúrák stb.) is meghatározza az adott személynek az intézményi struktúrában elfoglalt helye.

A területfejlesztési politika tárgya a térszerkezet változásába bizonyos célok mentén történő beavatkozás. Három beavatkozási mód határozható meg: a területrendezés, a regionális (gazdaság) politika és a területileg releváns ágazati és funkcionális politikák területi integrációja.

A területrendezés a földhasználat és - részben - az infrastrukturális fejlesztések (fỏleg állami beruházások) speciális térszerkezetével foglalkozó tervezési tevékenység. A regionális politika a területfejlesztés és az állami infrastruktúra-fejlesztés pénzügyi ösztönzöinek és költségvetési eszközeinek kerete. Az ágazati politikák nyilvánvalóan jelentỏs hatással bírnak a területfejlesztésre, ezért szükség van e politikák célkitüzései és a területfejlesztési politika célkitüzései közötti alapvetö harmonizációra.

A keleti VISION országokban a politikai változásokat követően a területi beavatkozás mindhárom módjának jelentős nehézségekkel kellett szembenéznie. 
A területrendezés számára a legfontosabb kihívást a megváltozott tulajdonosi, jogi és piaci feltételek jelentik. Ez különösen a városrendezésre igaz. A szocialista idöszak alatt kidolgozott terveket nem lehet az új körülmények között megvalósítani. A tulajdonosi helyzet - gyakran - még nem teljesen tisztázott. A hatóságok szembekerültek az ingatlanértékelés problémáival, az új tulajdonosokat nem lehet mindig egyértelmúen azonosítani, és a bírósági procedúra évekig is eltarthat. A mezőgazdasági földek állapotának és átalakítási lehetőségeinek további tisztázására van szükség. A helyi önkormányzatok nem rendelkeznek az ingatlanpiac irányításához szükséges pénzügyi eszközök felett.

A területrendezés másik nehézsége a jogi, igazgatási és tervezési rendszerben való bizonytalan meghatározottsága. A központi tervezés hierarchikus rendszerét felszámolták, de a különböző szinteken meghozott döntések közötti új kapcsolatokat nem határozták meg egyértelmủen. Számos országban a helyi önkormányzatok terveiben nem megfelelően tisztázott az alapvetơ nemzeti, vagy szélesebb nemzetkőzi érdekek teljesitése kikényszeritésének jogi útja. Mindamellett, tekintettel a jelenlegi és elkövetkezendô robosztus területi változásokra, a földhasználat és az infrastruktúra területi megjelenésének ellenőrzésére sürgösen létre kell hozni egy müködőképes területrendezési rendszert.

A legtöbb ország a politikai változásokat követỏen újraszabályozta a területrendezést. Ezek közül számos ideiglenes jellegú, és nem veszi teljes mértékben figyelembe a megváltozott feltételeket. A legtöbb országban átfogó új szabályozásra van szükség, amely meghatározza a kormányzati, gazdasági és társadalmi struktúrában a regionális és területrendezés új helyét.

A regionális politika jelentős kiigazítására van szükség. A központi tervezés hajdani rendszere csődöt mondott, annak módszere és eszköztára (hatalmas állami ipari beruházások megvalósítása, nagy összegü támogatások és ártorzitások, költségvetési bértámogatások a preferált térségeknek stb.) már nem alkalmazható tovább. Az országok többségében nincs több évre szóló költségvetés, sőt az éves tervet is többször módosítani kell. Ilyen feltételek között korlátozott bármilyen belátható időtávra szóló regionális gazdaságpolitika lehetősége. A költségvetéstervezésben alig alkalmazzák a programozási módszereket. Mind nemzeti, mind regionális és helyi szinten meg kell kezdeni a kormányzati finanszirozás és a költségvetés-tervezés intézményi átalakítását és módszertani megújitását. E téren támogatni kell a kezdeményezéseket, és a megfelelő tapasztalatoknak publicitást kell kapniuk.

A területfejlesztés jövőképe c. fejezetben felvázolásra kerültek a VISION térségben a területfejlesztésre váró kihívások, amelyek rámutatnak a területileg illetékes ágazati politikák sokkal intenzívebb koordinációjának és integrációjának szükségességére. A szektorális döntések minden szinten (szupranacionális, nemzeti, regionális és helyi) hatással vannak a térszerkezet fejlődésére. E politikák közötti horizontális koordináció elősegítheti azon intézkedések hatékonyságát, amelyek a VISION térség egészének gazdasági és társadalmi kohézióját szolgálják. 
A három beavatkozási mód közötti kapcsolat vonatkozásában a területfejlesztési jövőkép fö célkitüzései a következő korrekciókkal jellemezhetök.

- az illetékes ágazati politikák területi és ágazati integrációja irányába mutató területrendezés szélesebb körü elismerése,

- a regionális politikának az infrastruktúra-fejlesztés magába olvasztása felé mutató kiterjesztése, és

- a területrendezés és a regionális politika célkitüzéseinek, eszközeinek és folyamatainak harmonizációjának biztosítása.

Ebben az új rendszerben megfelelö helyet kell találni a határokon átnyúló és a transznacionális területi tervezés számára is. A területi tervezési rendszer integrált, rendszeresen alkalmazott részévé kell válnia. A tervezés e területére különösen igaz, hogy a részt vevö országok intézmény és eszkőzrendszere kulcsszerepet tölt be. Viszont ez nem jelenti azt, hogy az intézményi struktúra megegyezösége vagy különbözősége a transznacionális együttmüködés létrehozásának egyetlen kritériuma. Ebben a kontextusban különösen két terület fontos: az infrastruktúra-fejlesztés és a regionális politika strukturális (finanszírozási) eszközei és ösztönzöi. Ezek nemcsak a kủlönbőző országokhoz tartozó partnerek közötti együttmúködés számára fontosak, hanem a közösségi politika (mint a Strukturális Alpok végrehajtása) vonatkozásában az Európai Közösséggel való egyutttmúködés számára is.

Mint fentebb vázoltuk a VISION országok ,politikai piacán” nem fordítanak kellő figyelmet a területfejlesztési politika megértésének átfogó jelentöségére. Néhány ország esetében (és ezek között vannak nemcsak csatlakozásra jelöltek, hanem tagállamok is) az EU keretében tơrténö transznacionális tervezési gyakorlat segitheti annak nemzeti vonatkozású fejlesztését is.

Három alapvető aspektus alkotja a VISION dokumentumban vázolt célkitűzések megvalósításának alapjait:

- a különböző szinteken elhelyezkedő szereplők érdekeik és autonómiájuk döntéseik során történó kifejtésével és érvényesitésével vesznek részt a megvalósításban (szubszidiaritás - a szereplők),

- a transznacionális területi tervezés meghatározott területi és tematikus kontextusa (a területi kontextus),

- a stratégia megvalósítására rendelkezésre álló eszközök választéka (az eszközök).

a) A szereplök: a régiók és a területi közigazgatási szervek szerepe és funkciója

Az elmúlt 10 évben minden keleti VISION országban (beleértve a volt NDK-t is) jelentős változások mentek végbe a helyi önkormányzati rendszerben és a területi közigazgatásban. A legtöbb országban a területi közigazgatási rendszer reformjának fó célja a hierarchikus és centralizált rendszer megszüntetése, a helyi önkormányzat legalsó szintjének, azaz a városoknak és kőzségeknek a megerősítése volt. A politikai rendszerváltást követő első öt évben mérséklődött a területi középszint hatalma és hatásköre, a hierarchikus függőség viszonya megszünt. Néhány országban a választott területi szintủ önkormányzatot teljesen felszámolták, csak a központi 
kormányzat maradt meg; ha a választott testületek túlélték is a rendszerváltást, hatáskörüket jelentős mértékben szükítették. Számos országban a volt nagy községek jelentősen szétaprózódtak, aminek eredményeként a mai községek méretei jóval kisebbek. Gyakorlatilag mindenhol a helyi szint maradt az egyetlen központi kormányzat alatti, kiterjedt autonóm hatáskörrel rendelkező kormányzati szint.

A gazdasági fejlödés területi polarizációját és a keleti VISION országok többségében tapasztalható növekvő területi egyenlötlenségeket tekintve az átmeneti országok politikai-közigazgatási rendszerében a hiányos vagy gyenge területi szint fokozatosan egyre jelentősebb kérdéssé válik. A legtöbb helyen már létrehozták az új területi középszinteket, vagy kialakításuk most van folyamatban, bár néhány országban ez nem ölt választott helyi önkormányzati jelleget. Más országokban a meglévő - kisebb - régiók együttmüködését támogatják. Sem politikai lehetösége, sem indoka nincsen annak, hogy bizonyos politikai szervezeti modelleket elóírjunk a keleti VISION országok számára. Néhány követelményt azonban támasztani kell. A területi intézmények kialakításának garantálni kell a következő (minimális) feltételek javítását:

- a területi információ megfelelö regionalizációját;

- a regionális kezdeményezések mobilizációját;

- a regionális és helyi szereplök felhatalmazását az önkéntes nemzeti, határon átnyúló és nemzetközi együttmủködésekre;

- az EU regionális politikájának (partnerség, programozás, társfinanszírozás) végrehajtását.

A fenti követelményeket figyelembe véve kell megvizsgálni az új intézményi hálózat megvalósításának irányát az adott országokban.

Az Európai Unió regionális politikája a régiókon alapul, amelyek mint tervezési, programozási, finanszírozási és controlling, fejlesztési és határon átnyúló együttmüködési egységek a közösségi támogatás célterületei. A csatlakozó országoknak meg kell határozniuk saját NUTS egységeiket (többségük már megtette), mely egységekre vonatkozóan információkat kell összegyüjteniük, és fejlesztésükre programokat kell kidolgozniuk. Regionális szint(ek)en professzionális tervezési, programozási és végrehajtó ügynökségeket és különböző társadalmi, valamint érdek csoportok képviselöiböl felállított felügyelỏ szerveket lehet létrehozni, a fennálló közigazgatási rendszer megváltoztatásának szükségessége nélkül. Hosszú távon természetesen ésszerủ és kívánatos a közigazgatási szerkezet és a fejlesztési, programozási egységek harmonizálása.

b) A területi kontextus: a szubtérségek meghatározása, és szükségleteikkel összhangban a politikai lehetőségek érvényesitése

A területfejlesztési jövőkép a VISION térségre, mint egységes egészre került kidolgozásra. Nem tesz különbséget az Európai Unió tagállamai és a térség többi országa között. Minden ország részese a jövőbeli európai integrációs folyamatnak. Ugyanakkor azonban néhány szembetünő földrajzi és gazdasági különbség sajátos 
címzést és megközelítést kíván meg. A VISION dokumentum kidolgozása során e sajátos térségek két típusa került meghatározásra:

- Nagytérségek: több ország olyan régióit tömörítik, amelyek hasonló vagy egymást kiegészítő gazdasági szerkezettel rendelkeznek, vagy a múltban szoros gazdasági kapcsolatokat és együttmüködési partnerkapcsolatokat alakítottak ki. Ezek a transznacionális térségek, melyek a kapcsolatok újjáélesztése révén a dinamikusabb fejlődéshez elegendő gazdasági lendületet kapnának, és így határozottabb szerepet és funkciót tőlthetnének be a jövőbeli európai gazdasági térben.

- Határ menti kisebb térségek: ahol a különböző országok területei találkoznak, ahol a közlekedés, illetve más infrastrukturális fejlesztések, vagy a környezet sajátos problémái felmerülnek. Itt a megoldáshoz létfontosságú mind a nagymérvü transznacionális, mind a regionális szintü határon átnyúló együttműködés. E térségek „határon átnyúló akcióterületekként” írhatók le.

Ennek megfelelöen a VISION térségben a transznacionális területi együttmủködésnek különböző szintjei vannak. A horizontális (ágazatok közötti) egyưittmüködési funkció mellett ugyanilyen fontos a vertikális (szintek közötti) munkamegosztás, illetve a területfejlesztésbeli és a területi tervezésbeli együttmüködés. A szintek közötti munkamegosztásnak a szubszidiaritás elvén kell alapulnia.

A fent említett kritériumokkal összhangban meghatározható térségek bármelyikének, a nagytérségeknek éppúgy, mint a kistérségeknek a területi fejlesztésével kapcsolatban különbözỏ elvárások fogalmazhatók meg. A területfejlesztés jövőképe c. fejezetben meghatározott politikai lehetőségek alkothatják az alapját ezen igények megközelítésének. Az egyes térségekben a szereplök feladata meghatározni és alkalmazni azokat a politikai lehetőségeket, amelyek speciális feladatuk számára a legalkalmasabbak, s egyben a legtöbb haszonnal járnak.

c) Az eszközök: a területfejlesztési politikai lehetôségek alkalmazásának irányai

A központositott tervgazdaság időszakában az eröforrás allokáció ágazati és iparági elosztáson alapult. A tervcélokat és a pénzügyi eszközöket szektorális alapon osztották el, a területi dimenzió csak alárendelt szerepet játszott, ha egyáltalán figyelembe vették. A piacgazdaságokban, és kủlönösen az Európai Unióban a területi dimenziót a versenypolitika szempontjából jóval semlegesebbnek tartják, mint az egyes iparágakat és szektorokat, ezért a strukturális politikának sokkal megfelelőbb célterületei. Bár a gyakorlatban az ágazati megfontolások még fontosak, néha domináns szerepet játszanak, azonban a strukturális politikák területi dimenziójának jelentösége folyamatosan növekszik.

A privatizáció, a piaci környezet, az ágazati szervezetek közötti éles választóvonal eltủnése és a régiók közötti egyre növekvő egyenlőtlenségek minden keleti VISION országban a kormányzati ágazati és költségvetési rendszer megváltoztatására szólítanak fel. Minden országban történtek változások, de a regionális politika végső formája még nem tisztult le teljesen. 
A volt tervgazdaságok ár-, adó- és jövedelemszabályozási rendszere azzal, hogy alacsonyan tartotta a munkaerö, a telephely és az infrastrukturális szolgáltatások árát, automatikusan elősegitette az ipar területi terjedését, és hozzájárult a maximális számú munkahely létrehozásához. Az újonnan bevezetett adórendszert, amely jelentösen megdrágítja a munkaerőt és más termelési tényezőket, nem úgy tervezték, hogy megfeleljen e sajátos funkciónak, sőt néha pont ellenkezőleg hat. Következésképpen az elmaradott térségek fejlesztéséhez, a versenyképes fejlődés infrastrukturális előfeltételeinek megteremtéséhez, a szerkezetváltás elősegitéséhez és a magas munkanélküliséggel küzdő térségekben a munkahely teremtés támogatásához regionális gazdasági ösztönzö-rendszerre van szükség.

A VISION országok többségében léteznek ilyen és hasonló célokat szolgáló költségvetési eszközök és hitelek. Ezek a pénzügyi eszközök azonban különböző minisztériumok között oszlanak meg, szétaprózottak, és néha rosszul koordináltak. Ezért hatékonyságuk alacsonyabb, mint amilyen koordinált esetben lenne. Ésszerü és kívánatos a különbözổ költségvetési juttatásokat és forrásokat összevonni egy vagy néhány területfejlesztést szolgáló alapba, és biztositani szétosztásuk harmonizált ellenörzését. Ezen allokatív funkció legjobb telepítési helye egy közvetlenül a miniszterelnök alá rendelt területfejlesztési szervezet lenne (pl. Franciaország), vagy egy (nem ágazati) gazdasági minisztérium. A megvalósítandó eszközrendszer azonban nagymértékben fủgg az egyes országok kormányzati struktúrájától. Fontos, hogy az adott kormányzati szervezeteknek kell értékelniük a különböző kormányzati politikák és intézkedések területi hatásait, és olyan pozícióban kell lenniük, hogy azokat ténylegesen befolyásolni tudják.

A nemzeti területfejlesztési alapok megléte az EU strukturális alapjaihoz történö jövőbeli csatlakozás előfeltétele is, amikor majd lehetővé válik a kőzősségi támogatások társfinanszírozása. A kidolgozott programokra épülö koncentráció és allokáció, mint a strukturális alapok másik kritériuma, ugyancsak figyelmet érdemel, nemcsak az EU által támogatott projektek esetében, hanem a nemzeti források elosztását illetỏen is.

Az EU alapok elosztási folyamata diszkrecionális (megitélés szerinti) és nem automatikus. Ez azt jelenti, hogy minden egyes programot és projektet egyenként vizsgálnak meg és értékelnek, nincsenek eleve támogatandó projektek. Ajánlott ezt az elosztási elvet alkalmazni a nemzeti alapok esetében is. Ez csak decentralizált módon vihetó véghez, ezért területi szinten nagyon fontos a regionális fejlesztési tanácsok vagy valamilyen hasonló szervezetek létrehozása. Ezek a szervezetek sokkal jobban ismerik a helyi problémákat, és helyesebben tudnak dönteni a források elosztásával kapcsolatban.

A fejlesztési támogatások legmegfelelőbb formája a beruházásokat és munkahelyteremtést segítő költségvetési támogatás vagy kedvező hitelkondíció. Az adó, ár és egyéb engedmények versenypolitikai nézöpontból kétes eszközök. A „szabadkereskedelmi övezetek" és hasonló intézkedések nem konzisztensek az EU versenypolitikájával, azonban a regionális politika fontos eszközei lehetnek az infrastruktúrával felszerelt ipari parkok, tudományos-technológiai parkok és egyéb 
támogató szervezetek - mint pl. Üzleti Innovációs Központok, „inkubátorházak”, "technológiai parkok", ,joint venture támogató központok" (SEED) és „logisztikai központok" - létesitése.

Figyelmet kell fordítani arra, hogy bizonyos egyensúly alakuljon ki az infrastruktúra-fejlesztésre és a közvetlen munkahelyteremtést megvalósitó kis- és középvállalkozások támogatására fordított összegek között. Bármelyiknek a kiváltsága vagy figyelmen kívül hagyása csökkentené a hatékonyságot, és gyengítené a regionális politika pozitív hatásait.

\section{2) Területi integráció}

Európa (Oroszország nélkül) a Föld szárazföldi területeinek 4,4\%-át, népességének 10,4\%-át foglalja magába. Az európai kontinens stabilitása és biztonsága - és ezzel szoros kapcsolatban a versenyképessége - a jövő globalizálódó politikai és gazdasági világában csak annak gazdasági, társadalmi, politikai és területi integrációján keresztül biztosítható. Ezért a VISION térség teljes területe az európai integrációs folyamat területének tekinthető, bár - a különböző politikai, gazdasági és fơldrajzi tényezók miatt - az integráció sebessége az egyes országok esetében eltérö.

Az integráció fogalmának számos jelentése van. Ezek közül az egyik a területi integráció. A területi integráció azt jelenti, hogy az eltérő fôldrajzi helyek és térségek idő, költség és pszichológiai távolságok szempontjából „közelebb kerülnek” egymáshoz. Sủrủbb közlekedési és telekommunikációs hálózatok megteremtését jelenti, amely lehetơvé teszi a területek között az emberek, az áruk és az információ gyorsabb, rendszeresebb és bürokrácia-mentesebb mozgását. Azt jelenti, hogy amennyire csak lehet a határok átjárhatóvá és áttetszővé válnak. Ezen kívül a városok, régiók és más területfejlesztési szereplök közötti transznacionális együttmüködési hálózatok kialakulását eredményezi.

Minden szinten és szférában támogatni kell a társulásokat: nemzeti kormányzatok között, regionális és helyi önkormányzatok között, gazdasági, politikai és kulturális intézmények között, valamint a vállalkozások között. A városok és régiók közötti partneri kapcsolatok és hálózatok különösen fontosak. Az $16000 \mathrm{~km}$ szárazföldi határt figyelembe véve prioritást kell élvezniük a határon átnyúló együttmüködéseknek és az eurégiók kialakitásának.

A keleti VISION térség közlekedési hálózatában még mindig szúk keresztmetszetet jelentenek a határátkelöhelyek. A térség több mint 50\%-a tekinthetỏ határ menti térségnek. Ezért számukra nagy jelentőséggel bírnak a határátkelöhelyek. Az EU tagállamok közötti határoktól eltekintve, a $15400 \mathrm{~km}$ hosszú határon összesen 194 nemzetközi határátkelöhely van, azaz átlagosan $80 \mathrm{~km}$-enként egy. Néhány határon azonban a helyzet még ennél is rosszabb. Figyelembe véve, hogy a határokon átvezető útvonalaknak csak kevesebb, mint 40\%-át használják nemzetközi határátkelőként, a helyzet elfogadható költségek mellett is jelentős mértékben javítható. Sokkal bonyolultabb a helyzet azonban a folyó menti határoknál. A $3660 \mathrm{~km}$ folyó menti határszakaszon mindössze 54 híd található (ezek közül 21 volt a háborút megelőzően a hajdani Jugoszlávia területén). E határszakaszokon az új hidak 
építésének, illetve a régiek rekonstrukciójának, és a tengeri kapcsolatok megerốsitésének elsödleges feladatként kell megjelenniük. Ezek megvalósitásához nemzetközi támogatásra van szükség.

A területi integráció egyik legfontosabb előfeitétele a transzeurópai közlekedési hálózatok megteremtése. A hálózatok kidolgozása és elfogadása az EU tagállamokban a TEN program, a csatlakozó országokban pedig a TINA program keretében történik. Az európai közlekedési folyosók és a csatlakozó országok fỏ közlekedési vonalai a nem csatlakozó országok területére is elvezetnek. Amint lehetséges, létre kell hozni a hálózattervezés együttmüködési keretét az illetékes nemzeti és szupranacionális intézmények részvételével, amely magába foglalja a térség összes országát. Ehhez a TINA szerkezete kiindulási pontként szolgálhat.

A környezetvédelem, a szennyezés csökkentése, a természetvédelem és az árvízvédelem szintén közös feladatként jelentkeznek. Számos országban a légszennyezés nagyobb része külföldröl származik, a felszíni vízforrások - és a vízszennyezések jelentős része is az adott ország területén kívülről érkezik. Ezért az egyéni, koordinálątlan környezetvédelmi és árvíz megelőzési intézkedések eredménytelenségre vannak itélve. 'A természetvédelmi terulletek és az értékes ökoszisztémák többsége a határ menti térségekben található. A transznacionális területi tervezés keretében koordinált intézkedések a részt vevö országok számára sokkal eredményesebbek lesznek.

A területi tervezési kérdések nagy része szorosan kapcsolódik az EU csatlakozáshoz. A VISION térség 17 államából három EU tagállam, hét csatlakozó ország, hét pedig még nem kapcsolódott a csatlakozási folyamathoz. Az EU bővités időzítése és módja azonban a térség összes országára hatással lesz. A közösségi joganyaghoz való alkalmiazkodás és csatlakozás, a belépés elökészítése hatással lesz - és részben már most is hatással van - az adott országok területi szerkezetére. Még inkább így lesz ez a csatlakozást követően, amikor alkalmazásra kerulnek a közös agrárpolitika és a strukturális és kohéziós politika szabályozásai, intézkedései. A bővitésnek a jelenlegi tagállamokra is hatása lesz, beleértve Görögországot is, mint a CADSES tẹrség negyedik EU tagállama. E hatás különösen az EU jelenlegi határainál, az új tagállamokkal szomszédos térségekben válnak jelentőssé. A hatások természete nagymértékben függ a régiók versenyképességétől és gazdasági állapotától. Ezért $a z$ elöcsatlakozási periódusban különös figyelmet kell fordítani a térségek strukturális korrekciójára és megerősítésére. A szakaszos, fokozatos csatlakozási folyamat minden bizonnyal hatással lesz az addig még nem társult országokra és régiókra (a külkereskedelmi megállapodásokra, vámokra, utazás és munkavállalási szabályozásokra vonatkozóan). Még a bővítés első köre előtt intézkedéseket kell tenni, és megállapodásokat kell kötni, hogy az EU új-és folyamatosan változó - külső határai mentén maximalizálni lehessen a pozitív, és minimalizálni a negatív hatásokat.

A tapasztalat azt mutatja, hogy helyes volt az a döntés, miszerint a VISION térség teljes területét egy átfogó programtérségként kell kezelni. A jelentös különbségek ellenére a keleti VISION országok rendelkeztek egy bizonyos közös tapasztalattal, hasonló politikai és intézményi feltételekkel, illetve az átalakulás hasonló kihívá- 
saival néztek szembe, ennek következtében megfogalmazható a közös stratégia és jövőkép néhány alapvetö eleme. A VISION PLANET partnerei az elkövetkezendö évek során élénkiteni kivánják transznacionális területfejlesztési együttmüködésüket. Az ESTIA partnerek szándéka szintén a szorosabb együttmüködés, ezért megfontolásra javasolják a CADSES programtérség ún. INTERREG III keretprogramon belül való folytatását.

A Balti-tenger Régió példáját követve a CADSES térségben a területi tervezési együttmũködés állandósulását és intézményesitését jovasolják. A tapasztalat azt mutatja, hogy a multilaterális intézkedések olyan eredményeket is elérhetnek, amelyeket kétoldalú intézkedéseknek nem sikerült. A multilaterális megállapodások alkalmasabbak a területi tervezés Közép- és Kelet-Európában elégtelen pénzügyi és szellemi erőforrásainak figyelembe vételére. Az ilyen megállapodások, beleértve mind a tagállamokat, mind a nem tagállamokat, a csatlakozási folyamat állásától függetlenưl szolgálhatják a régiók területi tervezői közötti párbeszédet, és ezáltal erősíthetik a kohéziót és az egyuuttműködést a térségben.

\section{Összefoglalás}

\section{A kezdeményezés}

A VISION dokumentum a VISION PLANET, INTERREG II C projekt keretében került kidolgozásra. A kezdeményezö EU tagállamok Ausztria, Németország és Olaszország voltak, míg a részt vevő nem EU tagállamok a következők: Bulgária, Cseh Köztársaság, Horvátország, Jugoszlávia, Lengyelország, Magyarország, Románia, Szlovákia és Szlovénia. A dokumentum kidolgozását a német Bundesamt für Bauwesen und Raumordnung (Építésügyi és Területfejlesztési Szövetségi Hivatal) koordinálta.

A projekt célja az volt, hogy közös stratégiákat, irányelveket és intézkedéseket fogalmazzon meg a térség területfejlesztése számára, beleértve tizenkét európai ország teljes területét, illetve öt ország területének egy részét. A dokumentum célkitủzései, tartalma és metodikája több szempontból is hasonlóságot mutat más fontos európai transznacionális területi tervezési és fejlesztési dokumentumokkal. A hasonlóságok mellett azonban lényeges különbségek is felfedezhetók, amelyek az országok eltérö összetételéből fakadnak, valamint a korábbi dokumentumok kidolgozása óta megvalósult új fejlesztések következményei. A nem EU tagállamokban a gazdasági és társadalmi átalakulás jelentős mértékben elörehaladt, és ma már sokkal jobban meghatározhatóak annak területi következményei, de kihívásai is, mint ezelött. Továbbá az európai integrációs folyamat feltételei, követelményei és szakaszai is láthatóbbá váltak, területi hatásai sokkal alaposabban elemezhetök és tervezhetök. E változások feltárása a VISION kezdeményezés egyik sajátossága.

A VISION dokumentum két fö részből áll: a „Policy Options Paper” (Politikai Javaslatok) a területi tervezési együttmükődés legfontosabb célkitüzéseit és politikai lehetőségeit, illetve az intézkedésekhez tartozó javaslatokat foglalja össze. A „Background Report” (Háttérjelentés) a közös kidolgozási folyamat fontosabb 
megállapításait tartalmazza, és a „Policy Option Paper”-ben megfogalmazott célkitüzések és intézkedések megalapozásaként illetve magyarázataként szolgál. A „Background Report" végsö formába ơntése azonban csak 1999 második felében várható.

\section{Fö célkitũzések}

A területi tervezés és regionális politika fỏ célkitüzései közösek a többi európai országgal és térséggel. A teruletfejlesztési politikának hozzá kell járulnia a régiók versenyképességéhez, hatékonyságához és növekedéséhez; segíteni kell az országok közötti és az országokon belüli gazdasági és társadalmi kohéziót; biztosítania kell a természeti és kulturális örökség megörzését, a környezet védelmét és a fenntartható fejlödést. E célkitüzéseket azonban sajátos feltételek között kell megvalósitani. A térség országainak politikai, társadalmi és gazdasági átalakulása során az egyes célkitüzések között ma még számos ellentét tapasztalható. Mindezt súlyosbítják az országok között húzódó hosszú szárazfơldi határok, továbbá az egymástól való hosszú ideig tartó politikai és gazdasági elszigeteltség, ami csak egy további célkitüzéssel, a területi integráció érvényesülésével oldható fel.

\section{A területfejlesztés tóvlata}

A területfejlesztési politikák egyik sarokköve, hogy tekintettel a meglévö szerkezetek determináló hatására, az országok többségében tapasztalható csökkenó népességszámra és a gazdasági erőforrások korlátozott elérhetőségére a fejlesztést nagymértékben a jelenlegi térszerkezetre kell alapozni. A regionális és település struktúrában radikális változások nem várhatók, azok inkább a régiók és telepưlések belsó szerkezetében mehetnek végbe a jövőben.

A térszerkezet fejlesztésének legfontosabb feladatai:

- új vidék-város kapcsolat kialakitása az integrált fejlödés, a strukturális átalakulás, illetve a városokban és vonzáskörzetükben a szolgáltatás-kinálat javításának biztosításával;

- átfogó regionális politika keretében a felmerülő regionális egyenlőtlenségek kezelése oly módon, hogy az erőforrásokat a fejlödésben elmaradott, vagy komoly strukturális válsággal kủzdő térségekre fókuszáljuk, de a dinamikus, vezetö régiók fejlődésének veszélyeztetése nélkül, hiszen ezek a VISION térség országai számára létfontosságú nemzeti versenyképesség és növekedés hordozói;

- a periférikus helyzetböl származó akadályok és hátrányok mérséklése újabb határátke löhelyek megnyitásával, a határon átnyúló együttmúkődések élénkitésével és a közlekedési hálózat megfelelö fejlesztésével;

- a monokultúrás agrártérségek és az egyoldalú „egyvállalatú városok” gazdasági és foglalkoztatási szerkezetének diverzifikálása a kis- és középvállalkozások támogatásával, az endogén erőforrások kiaknázásával és a gazdaságpolitika különbözö intézkedéseinek kombinálásával; 
- a tudás és az információ jobb elérhetőségének biztosítása minden térségben az oktatási, kulturális és kutató intézetek megfelelő telepitésével és kialakitásával, ezen intézmények hálózatba szervezésével, és a legújabb információs technológiák felhasználásával;

- a települések és a tengerpart menti térségek közötti szervezett kapcsolat létrehozása, a tengerparti területi menedzsment müködésének fókuszába helyezve az egyưttmüködést és a harmonizált akciókat.

Az elmúlt évtizedben a térség országainak többségében dinamikus urbanizációs folyamat zajlott le. A városban élö népesség arányát tekintve nincsen jelentös különbség a térség nyugati és keleti fele között. A keleti városok fejlődését azonban elsősorban a közigazgatási funkciók, és az iparosítás határozta meg, míg a szolgáltatási funkciók alárendelt szerepet játszottak. Ráadásul a térség több országában hiányoznak vagy nem eléggé fejlettek a kisvárosok. Az elkövetkezö években e városok fejlesztésére kell helyezni a hangsúlyt. Lazítani kell a városok és települések túlzottan hierarchikus rendszerén, és az országokon belül a városok között egy sokkal differenciáltabb, többpólusú vagy több központú hálózat kialakítására van szükség, ami a specializációra és munkamegosztásra épülhet.

A legtöbb város belső szerkezete a gyors átalakulás időszakát éli. A belvárosi területek, a város-vidék kapcsolatok 'és a hatalmas lakótelepek funkciói gyorsan változnak. Számos város nincsen felkészülve ezekre a váratlan és szabályozatlan fejleményekre. Az ellenőrizetlen városi terjeszkedés, a túlnépesedés és a társadalmi szegregáció veszélyei fenyegetnek. Ezen új kihívások kezeléséhez a városvezetés és tervezés új formáira és eszközeire, illetve a lakáspolitika új kezdeményezéseire van szükség.

A vidéki térségek térbeli megjelenése és aránya - ugyancsak - többé-kevésbé hasonló a VISION térség nyugati és keleti felében. A vidéki térségekben a legfőbb különbség a mezőgazdasági foglalkoztatottak arányában és az infrastruktúra fejlettségi szintjében tapasztalható. Néhány VISION országban a mezőgazdasági foglalkoztatottak aránya magas, ami az elmúlt években még növekedett is. Elkerülhetetlen a vidéki foglalkoztatás átalakítása, ez azonban nem valósítható meg a vidéki települések, a földhasználat belsỏ átalakítása, illetve az infrastrukturális hálózatok fejlesztése nélkül. Az elkövetkezendő évtizedekben ez az egyik legnagyobb kihívás, amivel a VISION országoknak szembe kell nézniük.

A nemzetközi közlekedési hálózatok fejlesztésére irányuló növekvő erőfeszítések közös jellemzői a VISION országoknak. Mindenhol prioritást kapott a multimodális közlekedési folyosók épitése, hogy az országos közlekedési hálózatok jobban kapcsolódjanak a szomszédos országok közlekedési rendszereihez, valamint a közlekedésfejlesztés jobban megfeleljen a környezeti szabályoknak. A hálózatok fejlesztését a területfejlesztés fô célkitúzéseivel és folyamataival összhangban kell megvalósítani. Az elsődleges feladat a VISION térség keleti és nyugati fele közötti hiányzó közlekedési kapcsolatok kiépítése. Ugyanakkor javítani kell a VISION térség keleti részében a közlekedési infrastruktúrákat is, ahol az újra megélénkülő gazdasági kapcsolatok hatékony vasúti, közúti, tengeri és telekommunikációs összeköttetése- 
ket igényelhetnek. Az országok népességének nagy része számára az elérhetőség a kisebb térségeken belüli közlekedési lehetóségek (másodlagos hálózat) fejlesztése és javitása révén biztositandó. Ebben fontos szerepe van a tömegközlekedés fenntartásának és javításának. A közlekedési hálózat túlzottan hierarchikus és centralizált rendszerét a keresztirányú összeköttetésekkel lehet oldani.

Jelenleg a VISION térségben a telekommunikáció a legdinamikusabb gazdasági szektor. A közép- és délkelet-európai országok rendelkeznek a későn indulók elönyével, mivel telekommunikációs rendszereikben már a legmodernebb technológiákat alkalmazhatják. A telekommunikációs infrastruktúra modernizációja és fejlesztése hatalmas piaci lehetôségeket kínál, és vonzó a külfờldi befektetők számára. A VISION térségben a városi központokon kívül, hasonlóan az EU országok többségéhez még alacsony a telekommunikáció sưrüsége. Nagyon fontos, hogy a kormányzatok foglalkozzanak az infrastruktúra-fejlesztésnek és az ,információs társadalomba" való átmenetnek a területi aspektusával. A gazdasági és társadalmi fejlödéshez elöfeltétel a modern telekommunikációs infrastruktúrák és szolgáltatások elérhetösége a térség minden részében. A müszaki és gazdaságossági vonatkozások a beavatkozás lényeges teruletei annak érdekében, hogy a ritkábban lakott területeken csökkentsük a gazdasági és társadalmi különbségek felhalmozódásának kockázatát. A VISION országok jövőbeli területfejlesztése során ki kell használni a legutóbbi időszak eredményeit (pl. komparatív előnyöket) a vidékfejlesztés vagy a vonzó szolgáltató szektor számára. A területfejlesztési politikának hozzá kell járulnia e célhoz azzal, hogy növeli a tudatosságot, és támogatja a regionális szereplőket a lehetőségek kihasználásában.

A keleti VISION országokban az elmúlt évtizedben jelentős mértékben javult a környezet állapota. A termelés visszaesésének, illetve a szerkezetváltás és a környezeti intézkedések következményeként a legtöbb szennyező anyag kibocsátása csökkent. A környezet állapota azonban még messze áll a megkívánttól. Emellett a múlt örökségeként meg kell küzdeni a környezetet ért felgyülemlett károkkal, rendbe kell tenni az elhagyott külszíni bányákat, ipari területeket, szeméttelepeket. Ráadásul, különösen a vidéki térségekben, új veszélyek is jelentkeznek. Még nem teljesen tisztázott az újonnan privatizált erdők és természetvédelmi terưletek helyzete, és nincsen megfelelően biztosítva a nagy méretủ belvízelvezető és öntöző hálózatok fenntartása. A környezetvédelmi hatóságoknak meg kell birkózniuk a monitoring feladatával, és a - kisebb, de szétszórtabb - szennyezó források növekvő számával.

A régióban jól kiépített a nemzeti parkok hálózata. Védelmük terén és a szabályozások betartatásában azonban javulást kell elérni. Kevésbé fejlett azonban a védett tájak hálózata. A védett területek szétaprózottak, többnyire csak elszigetelt pontok, és csak ritkán tartalmaznak ökológiai folyosókat. A legértékesebb természeti ökoszisztémák a határ menti térségekben találhatók, ahol különösen kivánatos a közös - vagy legalább a koordinált - szabályozás és üzemeltetés.

A régió kulturális örökségekben gazdag, és a kultúrtájak nagy változatosságát mutatja. Megtalálható itt az európai kulturális és múvészeti korok többségének 
emléke, és Európában sehol nem lelhetö fel a népmúvészet és a vidéki építészet ilyen gazdagsága. A mủemlékek jelentős hányada azonban rossz, elértéktelenedett és pusztuló állapotban van. Regisztrációjuk egyes országokban hiányos, és nincsen teljesen összhangban az európai normákkal. A keleti VISION régió számos térségében egynél több nemzet él sajátos kulturális örökséggel, és vannąk olyan térségek, amelyekben ma már nem található nemzetek és vallási csoportok éltek. E kulturális örökségek megörzése a jelenleg ott élök feladata.

\section{Megvalósitás}

A célkitủzések megvalósításának elöfeltétele a területfejlesztés megfelelö intézményeinek, eszközeinek és intézkedéseinek felállítása, létrehozása, melynek három fö eleme a következö:

- a területi-közigazgatási rendszer átalakítása, amely minden szinten képes a terület- és városfejlesztési intézkedések végrehajtására;

- a területi tervezési rendszer kialakítása, amely alkalmas a területfejlesztés fontosabb irányelveinek összefogására és koordinálására;

- a pénzügyi és egyéb gazdasági eszközökkel rendelkezö regionális politika, amely a területfejlesztés célkitüzéseivel összhangban irányíța a gazdaságfejlesztési folyamatokat.

A keleti VISION országok túlnyomó többsége unitárius ország, a közigazgatási régióknak korlátozott hatásköre van. Ezzel szemben az önkormányzatok viszonylag széles jogi és pénzügyi autonómiával rendelkeznek. Az elmúlt években a legtöbb ország intézkedéseket és jogi szabályozásokat kezdeményezett a regionális hatóságok létrehozására és/vagy megerősitésére azzal a céllal, hogy képesek legyenek megvalósítani a regionális fejlesztést és területi tervezést, illetve a határ menti együttmüködési projekteket.

A területi és várostervezésnek gazdag hagyományai vannak az érintett országok többségében. Az elmúlt évtizedekben azonban nem a piaci körülmények, hanem a központi tervezés rendszerének feltételei között gyakorolták azt. A várostervezést mindenekelött az új ingatlanpiachoz és tulajdonosi feltételekhez, az új társadalmi, környezeti és pénzügyi szempontokhoz kell igazitani. A területi tervezést szükséges kiegészíteni a szubszidiaritás új követelményeivel, azaz a nemzeti, regionális és helyi hatóságok hatáskörének megosztásával, továbbá a tervezésben, fejlesztésben tapasztalható új folyamattal, ami a társadalmi részvételre épül. A területi tervezési szakma számára új kihívást, de egyben új lehetőségeket jelent a transznacionális területi tervezés.

A keleti VISION országokban a piaci erök megjelenésével felerösödtek a területi egyenlötlenségek. Ezért gazdasági és pénzügyi eszközökre van szükség a kiegyensúlyozottabb regionális fejlödés biztosítása érdekében. Jelenleg a legtöbb országban szükösek a területfejlesztésre forditott pénzügyi források, amelyek több kormányzati szerv között oszlanak meg. Ezek koordinációja a területfejlesztési célkitüzések szempontjából nem megfelelö. A kormányzati struktúrán belül meg kell erösíteni a regionális és területfejlesztési politikák szerepét és funkcióját. Ennek módja a kü- 
lönbözỏ országokban azonban azok közigazgatási hagyományaihoz igazodva, eltéró lehet. A regionális politika eszközeit ki kell egésziteni a versenypolitika követelményeivel, a különböző ágazatok egyenlő kezelésével és a szubszidiaritás elvével. A legtöbb VISION ország részesül az Európai Unió PHARE és ISPA támogatásából, - és a csatlakozást követően - e régiók többsége a Strukturális Alapokból támogatott 1 . célkitüzés területeihez fog tartozni. Ezért a regionális politikai eszközöket és intézményeket ki kell egészíteni a Strukturális Alapok alapelveivel (koncentráció, addícionalitás, progranozás, partnerség). A nemzeti források allokációja során ugyancsak célszerủ ezen elvek alkalmazása, bár a támogatottság kritériumainak nem szükséges azonosnak lenniük.

A VISION dokumentum elsödleges célkitüzése a területi integráció elösegitése az érintett országokban és azok régióiban. A dokumentum kidolgozása során az olyan transznacionális kérdések kaptak hangsúlyt, mint a határátkelőhelyek számának növelése, a határon átnyúló környezetvédelem, árvízvédelem, a természeti és kulturális örökség védelme, a közlekedési és egyéb infrastruktúra-fejlesztési együttmưködések. Egy átfogó területi tervezési célterületnek tekintettük az egész térséget, nagymértékủ váitozatosságával és számos közös jellegzetességével, illetve a közös érdekekkel együtt. Ahhoz, hogy a területfejlesztési problémákat közvetlenebbül kezelhessük, szükség volt néhány kisebb térség meghatározására, amelyekre speciálisabb fejlesztési célokat és feladatokat lehet meghatározni. A hosszú munka során felhalmozódott tapasztalat, és a még megoldásra váró feladatok sokfélesége azt kivánja, hogy a dokumentum kidolgozása folyamán kialakult együttmüködés tartóssá váljék. 


\section{1. ÁBRA}

Országok és régiók a VISION PLANET térségben (Countries and Regions in the VISION PLANET Area)

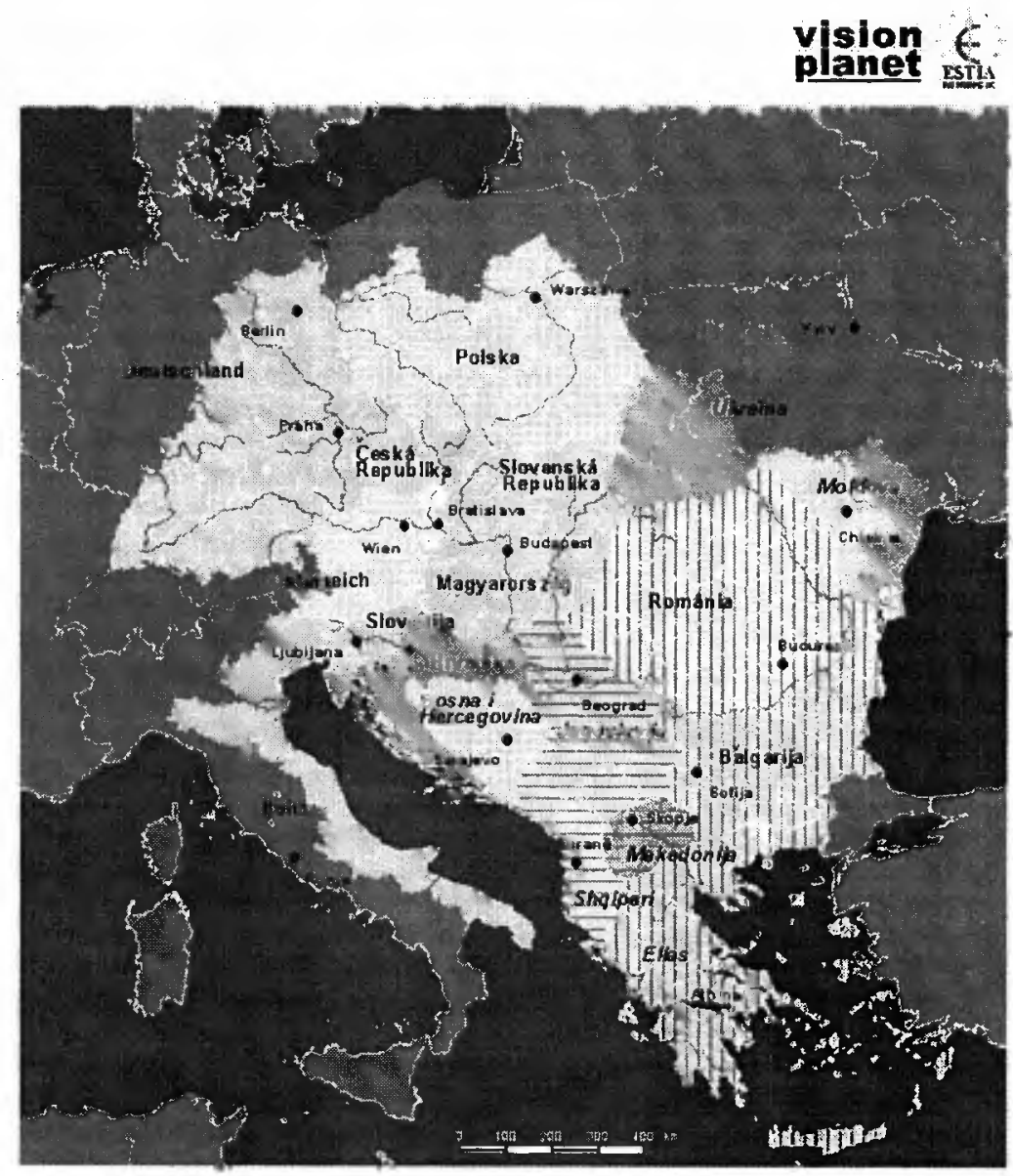

3. Országok és régiók a VISION PLANET térségben

A dőlt betüvel szedett országok még nem teljes jogú résztvevöi a VISION PLANET térségnek U/lESTIA partner $=$ ESTIA megfigyelö 
A közép-európai, a Duna menti és az adriai térség integrált területfejlesztési stratégiája Tér és Társadalom 13. évf. 1999/1-2. 195-251. p.

\section{2. ÁBRA}

\section{Városhálózat, központok} (Urban Centres System)

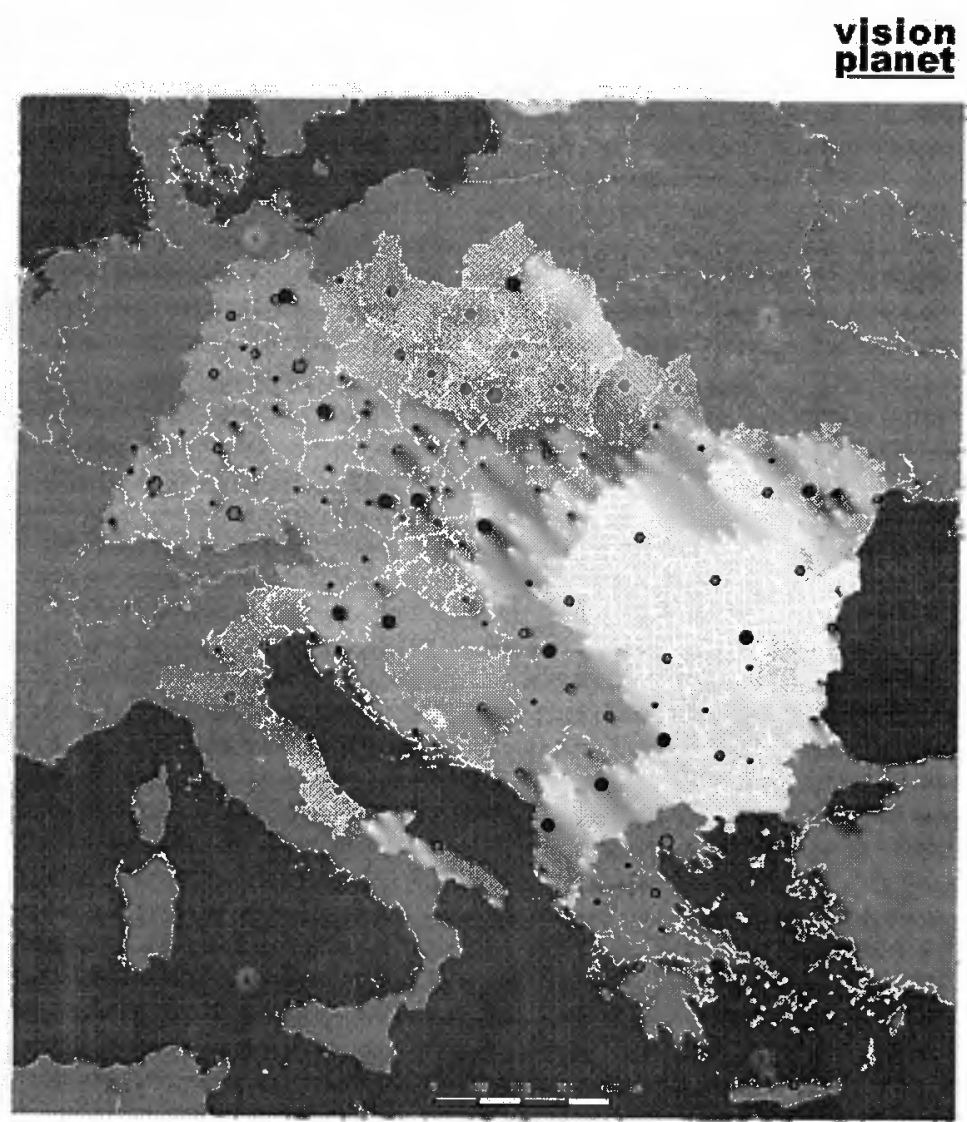

A városok funkciói és a nemzeti városhálózatok

- Föváros

- Európai jelentőségü város

- Országos jelentőségü város

- Regionális jelentõségü város 